\title{
EMPHATIC POLARITY IN EUROPEAN PORTUGUESE AND BEYOND
}

\section{ABSTRACT}

This paper deals with denials. 'Emphatic polarity' is here approached from a welldefined perspective that focuses on the syntactic expression of reversing reactions to assertions.

Three syntactic strategies to convey emphatic affirmation in the Romance languages are described and their distribution across languages elucidated, namely: the verb reduplication strategy, the si que (AFF that) strategy, and the sentence-final $\mathrm{sim} / \mathrm{s}$ istrategy. In order to account for the common traits of the structures displaying emphatic affirmation and concomitantly for their restricted cross-linguistic availability, the paper argues for the hypothesis that: (i) the functional categories $C$ (encoding relative polarity features) and $\Sigma$ (encoding absolute polarity features) are jointly involved in the syntactic expression of emphatic polarity and must be both phonologically realized in the relevant structures; (ii) verb movement in relation to the functional heads $C$ and $\Sigma$ (the topmost head of the IP domain) plus the specificities of the polarity lexicon are the main sources of variation across the Romance languages. Under this hypothesis, (i) is the unifying factor that lies behind the variation emerging from (ii). In its final section the paper briefly discusses emphatic negation. Two patterns are identified that parallel respectively the si que pattern and the sentence-final sim/síp pattern.

\section{Introduction}

Farkas \& Bruce (2010) distinguish between initiating and responding assertions, the former associated with absolute polarity features only, the latter also bearing relative polarity features (cf. Pope 1976). In the system devised by Farkas \& Bruce (2010), the absolute polarity features are [+] and [-], roughly corresponding to aff(irmation)/neg(ation) in current syntactic literature, and positive/negative in Pope (1976). The relative polarity features, on the other hand, are [same] and [reverse], roughly corresponding to agreement/disagreement in Pope (1976). The examples in (i) and (ii) below illustrate the available combinations of relative and absolute polarity features in responding moves, which are either reactions to assertions or reactions to polar questions (cf. Farkas and Bruce 2010: 109). 
(i) Anne: Sam is home./ls Sam home?

Ben: Yes he is. [same, +] (positive confirming assertion)

Connie: No, he isn't. [reverse, -] (negative reversing assertion)

(ii) Anne: Sam is not home./ls Sam not home?

Ben: Yes, he is. [reverse, $\left.{ }^{+}\right]$(positive reversing assertion)

Connie: No, he isn't. [same, -] (negative confirming assertion)

I take the exclusive features of responding assertions, that is, relative polarity features, to be grammatically encoded in the $\mathrm{CP}$ domain, whereas absolute polarity features are encoded in $\Sigma P$, the topmost functional projection in the IP domain. Thus the two sets of features are independently expressed by different functional heads, and all combinations of features from different sets are available (as illustrated in (i)(ii) above). Moreover, I will work with the hypothesis that whenever $\mathrm{C}$ bears relative polarity features either $C$ or $\Sigma$ must be phonologically realized, thus have lexical content at some stage in the derivation. That is to say, relative polarity features induce, by hypothesis, a strong property (understood as a requirement for phonological realization) associated with at least one of the polarity-encoding heads, resulting in strong $C$ or strong $\Sigma\left(C^{*}\right.$ or $\Sigma^{*}$, in the notation of Roberts 2001, 2004; Roberts and Roussou 2003). ${ }^{1}$ In minimal polar answers either $C$ or $\Sigma$ get lexically/phonologically expressed (e.g. sim answers in EP lexicalize C while bare verb answers in EP lexicalize $\Sigma$ ). Emphatic polarity results from the third logical option: attributing the strong/PF property to $C$ and $\Sigma$, which must then be both given phonological content. On syntactic grounds, this third option can, in principle, be

\footnotetext{
1 Cf. Roberts (2001:100):"Roberts and Roussou designate a functional feature F which requires PFrealization as $\mathrm{F}^{*}$. The diacritic * is distributed randomly across the inventory of features in each language (...). The overall conception of the lexicon, then, is that it contains the following elements:

(88) a. lexical categories

b. substantive universals encoded as features of functional heads

c. * assigned in a language-particular fashion to (b)

$\mathrm{F}^{*}$ must have a PF-realization, and this realization can be achieved in three ways: by Move, by Merge (lexical insertion) or by both together. Again, which option is taken depends on the lexicon, but the most economical is always preferred". I will not be assuming other aspects of Robert's (2001) theory of $\mathrm{F}^{*}$.
} 
freely implemented but it is expected to result in pragmatically adequate utterances only when the relevant structures bear the relative polarity feature [reverse] and, in particular, are reversals of a previous assertion. This is the type of structure and discourse context I will be interested throughout the paper.

Theoretically, the analysis argued for in this paper belongs to the Holmberg-style family of analyses for answering systems in treating emphatic polarity as a product of the interaction between the polarity-encoding head $\Sigma /$ Pol and CP (or some specific category belonging within the CP space). ${ }^{2}$ It departs from Holmberg's work, however, in taking unmarked polar answers to be structurally different from emphatic ones. The latter typically appear as reversals of a previous assertion and are structurally more complex than the former. The analysis put forth in this paper departs from the approach to emphatic polarity undertaken by Kandybowicz (this issue) in not making use of a specific functional projection to convey polarity emphasis. Although European Portuguese like Nupe (Kandybowicz 2007, this issue) displays verb reduplication as a means to express emphatic polarity, European Portuguese differently from Nupe shows no compelling evidence to posit the existence of a low Emph(asis)P, positioned in the left periphery of the $\mathrm{vP}$, that should be added to the inventory of EP functional projections. ${ }^{3}$

\footnotetext{
2 See Holmberg (2001, 2003, 2005, 2007, this issue). Cf. Batllori and Hernanz (this issue); Poletto and Zanuttini (this issue).

${ }^{3}$ The main empirical differences between Nupe and European Portuguese emphatic verb reduplication are summarized below (cf. Kandybowicz 2007, this issue; Martins 2007). Theoretically interesting as it certainly is, a thorough comparison between the verb reduplication structures of European Portuguese and Nupe is out of the scope of the current paper.

(i) NUPE VERB REDUPLICATION
}

Limited to root domains? No.

Speaker's commitment to absolute truth of proposition? No.

Compatible with narrow constituent focus? No.

Typically reversing (in the sense of Farkas/Bruce 2010)? No.

Compatible with negation? Yes.

(ii) EUROPEAN PORTUGUESE VERB REDUPLICATION Limited to root domains? Yes.

Speaker's commitment to absolute truth of proposition? Yes.

Compatible with narrow constituent focus? Yes/No (depending on how focus is marked).

Typically reversing (in the sense of Farkas/Bruce 2010)? Yes. 
European Portuguese (EP) will be the main source of empirical data, but comparison with other Romance languages will be central to the discussion throughout the paper. The present investigation is primarily directed towards increasing our understanding of the syntax of those sentences unequivocally expressing positive denial (i.e. sentences bearing the features [reverse, +] and expressing reactions to assertions). This particularly marked dimension in answering systems (cf. Pope 1976: 118ff.; Farkas and Bruce 2010), which I will refer to as emphatic affirmation, will then be briefly put in parallel with emphatic negation. ${ }^{4}$

The data used in the present study are intuitive ${ }^{5}$ and their analysis and discussion are couched within the generative framework (Chomsky 1995 and subsequent work). With respect to the functional architecture of the clause, it will be assumed that there is an overall parallel between affirmative and negative sentences, meaning that every clause includes the polarity encoding head $\Sigma$ where aff/neg features are located (cf. Laka 1990; Zanuttini 1994, 1997). ${ }^{6}$ I take $\Sigma$ P to be (in the Romance languages dealt with in this paper) the topmost projection in the IP space. ${ }^{7}$ I further assume that verb movement, targeting different heads in the functional domain, is a matter of

Compatible with negation? No.

4 Denials can be positive or negative, respectively [reverse, + ] and [reverse, - ]. On the marked status of denials, see. Farkas and Bruce (210:101): "[We take] denials to be special conversational moves that commit their author to the complement of the denotation of a declarative sentence placed on the Table by the preceding move. Denials are highly marked and therefore they must be explicit and must be signaled $(. .$.$) denials are marked moves in our terms because the proposition the author of a$ denial commits to cannot become a joint commitment in a coherent discourse without retraction on the part of another participant, and therefore the issue placed on the Table by the initial assertion cannot be removed in a canonical way”. Cf. also Farkas and Bruce (2010:114): "(...) (iv) We expect [reverse] to be more marked in denials than in reverse answers (...). (v) We expect the [reverse, + ] combination to be specially marked relative to [reverse, - ]".

5 I am most grateful to Rosario Álvarez, Montse Batllori, Ricardo Etxeparre, Mary Kato, Jairo Nunes, Cecilia Poletto and an anonymous reviewer for their generous and insightful assistance with, respectively, the Galician, Catalan, Spanish (Montse Batllori and Ricardo Etxeparre) Brazilian Portuguese (Mary Kato and Jairo Nunes) and Italian (Cecilia Poletto and anonymous reviewer) data. ${ }^{6}$ These are the absolute polarity features [+] / [-] of Farkas and Bruce (2010). I will prefer the terms aff/neg, commonly used in the syntax literature.

${ }^{7}$ See Laka (1990); Zanuttini (1994, 1997); Costa et al. (2012). 
parametric setting and lies behind different manifestations of syntactic crosslinguistic variation.

It is not my purpose in the current paper to undertake a cartographic approach to the CP space. So, I will use CP as cover term for what might well be different categories within the CP domain. I may do otherwise when referring to analyses proposed by other authors.

In section 2 different syntactic strategies found in European Portuguese and Romance to express emphatic affirmation are described and their distribution across languages elucidated. In section 3 the verb reduplication strategy and the sentencefinal sim strategy, found in European Portuguese, as well as the si que strategy found in Spanish and other Romance languages are given structural analyses that will be shown in section 4 to thoroughly account for: (i) all the properties of the monosentential verb reduplication construction and its unavailability in most Romance languages, including Brazilian Portuguese (ii) the unavailability of the si que strategies in European Portuguese and Brazilian Portuguese; (iii) the contrast between Galician, which allows all the three strategies, and European Portuguese, that excludes the si que sentences, (iv) the different word order patterns found in European Portuguese when unmarked answers including the word sim are compared with emphatic responses. Section 5 deals with emphatic negation showing how the proposed analysis of emphatic affirmation structures makes the right predictions with respect to the workings and crosslinguistic distribution of structures with sentence-final negation. Section 6 concludes the paper, summarizing the main findings and their contribution to a better understanding of the syntax of emphatic polarity in natural language.

2. Three syntactic strategies to express emphatic affirmation in the Romance languages

Emphatic affirmative responding assertions establish the untruth of a preceding negative statement and appear either in the context of a preceding declarative sentence or of a tag question presupposing a negative answer. The context of polar tag questions favors ellipsis as generally observed in polar answers, although elliptic sentences are also licensed in the context of a preceding statement (see (1) and (3) below). Independently of the presence or absence of ellipsis, emphatic affirmative 
sentences express responsive denial through reinforced affirmative polarity. Different strategies emerge in the Romance languages to convey the relevant type of emphatic affirmation. European Portuguese, for example, has an option between the verb reduplication strategy exemplified in (1)-(2) and the sentence-final sim strategy exemplified in (3), while Spanish disallows the verb reduplication strategy and preferably displays the si que strategy illustrated in (4)-(5), that is not available in European Portuguese.

European Portuguese

(1) [A] a. $O$ João não comprou o carro. the João not bought the car 'John did'nt buy the car.'

[B] b. O João comprou o carro comprou. [Verb reduplication] the João bought-3SG the car bought-3SG

c. Comprou comprou. bought-3SG bought-3SG 'John did buy the car.'

(2) [A] a. Aqui nunca chove, pois não? here never rains, POIS [= CONFIRMATIVE WORD] NEG 'It never rains a here, does it?'

[B] b. Chove chove. [Verb reduplication] rains rains 'Yes, it DOES'

(3) [A] a. Estou a ver que ele não gosta de animais. am to see that he not likes of animals 'I can see that he doesn't like animals'

[B] b. Ele gosta de animais sim. he likes of animals AFF

C. Gosta sim. [sentence-final sim] likes AFF 'He does like animals.' 
Spanish

(4) $[\mathrm{A}]$

a. Juan no se compró el coche.

Juan not SE bought the car

'John did not buy the car.'

[B] b. Juan sí (que) se compró el coche. [síque]

Juan AFF that SE bought-3SG the car

'John did buy the car.'

(5) [A] a. Aquí no llueve nunca, ¿verdad?

here not rains never, true

'It never rains here, does it?'

[B] b. Sí (que) llueve.

[síque]

AFF that rains

'Yes, it DOES'

The table below shows the distribution of the three strategies exemplified in (1) to (5) across some of the Romance languages. ${ }^{8}$ In the next section we will be

\footnotetext{
${ }^{8}$ One of the reviewers refers that Italian allows "some instances of verb repetition". This does not mean, however, that Italian displays verb reduplication with the properties described in section 4 below. Two facts suggest that in the relevant cases we are not dealing with mono-sentential structures in Italian, in contrast to European Portuguese. First, sentences like (i-B)-(ii-B) below do not constitute a single intonational unit, a pause typically separates the final verb from the preceding sentence, and the repeated sentence-final verb is unstressed, with focus falling on "bene" in example (i-B) (cf. in section 4 the intonation pattern of EP verb reduplication structures); second, speakers for whom the verb sentir requires a locative clitic (i.e. sentircl) necessarily repeat the clitic (see (ii-B) and compare in section 4 the ban against repeating the clitic in European Portuguese). I am most grateful to one of the reviewers and Cecilia Poletto who kindly made these facts available to me. Further inquiry into the Italian instances of "verb repetition" are beyond the scope of the current paper. Also Brazilian Portuguese (and presumably languages in general) allows sentence repetition as a possible means to express emphasis, but it does not permit EP-type mono-sentential verb reduplication.

(i) A: Non sente bene. (example provided by the reviewer)

not feels well

'He/she doesn't feel well.'

B: Sente bene, sente.
} 
concerned with putting forth an analysis of the relevant constructions that may explain the observed cross-linguistic distribution. We will concentrate though on the European Portuguese facts and will then contrast them with the Spanish, Catalan, Brazilian Portuguese and Galician data. ${ }^{9}$ Occasionally, Italian will also be taken into consideration. ${ }^{10}$

\begin{tabular}{lcccccc}
\hline & BP & EP & Galician & Spanish & Catalan & Italian \\
\hline Verb reduplication & $*$ & $\sqrt{ }$ & $\sqrt{ }$ & $*$ & $*$ & $*$ \\
Si (QUE) & $*$ & $*$ & $\sqrt{ }$ & $\sqrt{ }$ & $\sqrt{ }$ & $\sqrt{ }$ \\
Sentence-final sim/si & $\sqrt{ }$ & $\sqrt{ }$ & $\sqrt{ }$ & $\sqrt{ }$ & $\sqrt{ }$ & $\sqrt{ }$ \\
& & & & & & \\
\hline
\end{tabular}

Table 1: Emphatic affirmation patterns across the Romance languages

At prima facie it would seem that the verb reduplication strategy is available in the languages that display bare verb answers to yes/no questions, while the languages that exclude verbal answers as minimal affirmative answers to yes/no questions would also exclude emphatic verb reduplication. European Portuguese is a language of the former type as exemplified in (6) while Spanish is a language of the latter type,
feels well feels
'He/she does feel well.'

(ii) A: Non ci sente bene. (example provided by Cecilia Poletto's personal communication)

not $\mathrm{CL}$ feels well

'He/she does feel well.'

$\mathrm{B}$ : $\mathrm{Ci}$ sente, $\mathrm{Ci}$ sente.

$\mathrm{CL}$ feels $\mathrm{CL}$ feels

'He/she does feel well.'

${ }^{9}$ See the papers by Batllori and Hernanz (this issue) and Poletto and Zanuttini (this issue) for further details on the si que strategy, respectively in Spanish/Catalan and in Italian. I am putting aside here the fact that in Spanish and Galician the presence of que is optional in this construction while in other languages it may be obligatory (Italian), strongly favored (Catalan) or excluded (French).

${ }^{10}$ Although I do not have enough information on French to introduce it in the picture, it is clear that it patterns with Spanish, Catalan and Italian in licensing the si (que) strategy (with no realization of que) but not the verb reduplication strategy. 
as exemplified in (7). ${ }^{11}$ Brazilian Portuguese, though, has bare verb answers as the unmarked option for a positive reply to a yes/no question (see (6) below) but, significantly, does not allow the verb reduplication strategy as a means to express positive denial. This adds some challenge to the issues to be tackled in the next sections, so as the somehow unexpected dissimilar behavior of the cognate polarity words sim (AFF in Portuguese) and sí(AFF in Spanish, etc.) does as well. ${ }^{12}$

\section{European and Brazilian Portuguese}

(6) $[\mathrm{A}]$ a. $O$ João \{comprou / tinha comprado\} um carro?
the João bought-3SG / had bought a car
'Did João buy a car?' / 'Had João bought a car?'

[B] b. Comprou. / Tinha.

bought-3SG had-3SG

11 The fact that Spanish disallows bare verb polar answers is not just the effect of the unavailability of VP Ellipsis in the language (cf. Costa et al. 2012), as the examples below, with intransitive verbs, demonstrate (compare the ungrammaticality of (iib) with the grammaticality of (iiib)):

(i) [A] a. ¿Llamó Juan?

called Juan

'Did John call?'

[B] b. * Llamó.

called

'Yes, he did.'

(ii) [A] a. ¿Llueve?

rains

'Is it raining?'

[B] b. * Llueve.

rains

'Yes, it is'

(iii) [A] a. ¿Qué hay?

what there-is

'What's the matter?'

[B] b. Llueve.

rains

'It's raining.'

12 The words sim (European and Brazilian Portuguese) and sí/si /si (Spanish, Catalan, Italian,

Galician and French) are the outcome of the Latin adverb SIC 'so, in this way, in this manner'. 
'Yes, \{he did/he had\}.'

Spanish

(7) $[\mathrm{A}]$

a. Juan se \{compró/ ha comprado\} un coche?

Juan SE bought-3SG/has bought a car

[B] b. *Compró. / *Ha.

bought-3SG has

c. Sí.

AFF

'Yes, \{he did/he had\}.'

3. The interplay between $\mathrm{CP}$ and $\Sigma \mathrm{P}$ in emphatic affirmation

In order to account for the common traits of the structures displaying emphatic

affirmation in the Romance languages in tandem with their restricted cross-linguistic distribution, I will pursue here the hypothesis that: (i) the functional categories $\mathrm{C}$ and $\Sigma$ must be jointly involved in the syntactic expression of emphatic polarity (understood as denying responding assertiveness) and must be both phonologically realized in the relevant structures; 13 (ii) verb movement in relation to the functional heads $C$ and $\Sigma$ plus the specificity of the polarity lexicon are the sources of variation across the Romance languages. Under this hypothesis, (i) is the unifying factor that lies behind the variation emerging from (ii).

To be more concrete, the proposal is that only languages that independently allow verb movement to $\Sigma$ and verb movement to $C$ display the verb reduplication strategy. The availability of the si que strategy, on the other hand, depends on the language having the right type of lexical element, namely an affirmative $\Sigma$-word. The sentencefinal $\mathrm{sim} /$ sístrategy is available in languages with verb movement to $\Sigma$ as well as in

\footnotetext{
13 In previous unpublished work with João Costa, we have suggested that the distinction between strong and weak functional heads has place in grammar. The distinctive property of strong functional heads would be the fact that they require visibility at PF. Thus a strong functional head is licensed if and only if it is given phonological content at PF, or in other terms, if it is lexicalized. Lexicalization may arise under syntactic merger, under head or XP-movement, or under morphological merger. Cf. section 1 above.
} 
languages displaying the si que strategy. It is therefore the least cross-linguistically constrained of the three options.

I take the allowance/disallowance of bare verb answers in a particular language as the crucial test to determine whether the language has verb movement to $\Sigma$ or not, the former option depending on $\Sigma$ being $V$-related. The $\pm V$-relatedness of a given functional head is a matter of parametric variation across languages and across structures within a single language. I use here the term ' $V$-relatedness' in a descriptive pre-theoretical vein to refer to the occurrence/absence of $\mathrm{V}$-movement with respect to a particular functional category. What matters with respect to the emphatic affirmation sentences under discussion is that $V$ is attracted to $\Sigma$ in Portuguese, but not in Spanish and other Romance languages. This is typical parametric variation in terms of $\mathrm{V}$-relatedness.

With these considerations in mind, we are now in a position to move forward in accounting for each one of the syntactic strategies to express emphatic affirmation described in section 2. and to observe what they have in common.

The EP verb reduplication pattern is to be analyzed as an instance of phonetic realization of multiple links of the verbal chain (Nunes 2001, 2004). It is derived with verb movement to $\Sigma$, followed by verb movement to $\mathrm{C} .{ }^{14}$ The double phonetic

\footnotetext{
14 Independent supporting evidence for these two instances of movement in sentences with verb reduplication is given in Martins (2007). The placement of -ly adverbs offers additional evidence for verb movement beyond $\mathrm{T}$ (ense) in sentences with verb reduplication. These adverbs may usually surface in preverbal or post-verbal position in European Portuguese, as they adjoin to IP or TP while the verb is in T (Costa 1998). Verb reduplication, however, blocks the availability of the preverbal position as illustrated below. This is expected if, as proposed here, the verb moves higher in verb reduplication declaratives than in regular declaratives (compare the sentences in $A$ with the sentences
} in $B)$.

(i) [A] $O$ João frequentemente não faz os trabalhos decasa. the João frequently not does the works of home 'Frequently, João doesn't do his homework.'

[B] *O João frequentemente faz os trabalhos de casa faz. the João frequently does the works of home does 'Frequently, João actually does his homework.'

(ii) [A] $O$ João não faz frequentemente os trabalhos de casa. the João not does frequently the works of home 'João doesn't frequently do his homework.' 
realization of the verb is possible because the higher copy undergoes morphological reanalysis with $\mathrm{C}$ (resulting in a $\mathrm{C}^{0}$ category) and so becomes invisible to the Linear Correspondence Axiom (LCA). ${ }^{15}$ As a last step of the derivation, movement of the remnant $\Sigma \mathrm{P}$ to Spec,TopP (an instance of IP-topicalization) places the clausal constituent in initial position and the reanalyzed $\mathrm{C}$ position (phonologically expressed by the verbal copy) in sentence-final position. For the details on how deletion of lower copies and linearization proceed, so that (8c) is spelled out as (8b), see Nunes (2004) and Bošković and Nunes (2007). Verb movement to $\Sigma$ generally licenses VP Ellipsis (VPE) in European Portuguese, as far as the appropriate discourse antecedent for VPE is available (cf. Martins 1994; Costa et al. 2012). Whenever VPE arises, the verb is the only element in the topicalized $\Sigma P$ that gets phonologically realized, as illustrated in (9).

Emphatic verb reduplication (without VPE)

a. Ele não comprou o carro.

he not bought the car

'He didn't buy the car.'

[B] b. Ele comprou o carro comprou.

he bought the car bought

'He did buy the car.'

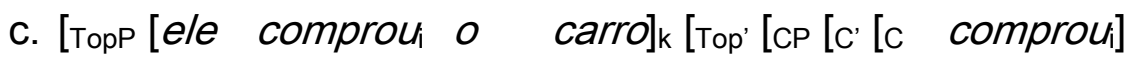

he bought the car bought

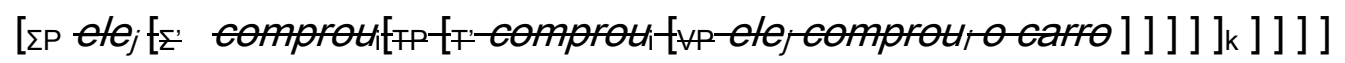

[B] $O$ João faz frequentemente os trabalhos de casa faz.

the João does frequently the works of home does

'João actually does frequently his homework.'

15 I am adopting here the insights of Nunes $(2001,2004)$ on the linearization of non-trivial chains under the Copy Theory of Movement (Chomsky 2000, 2001). In particular I follow Nunes' idea that the phonetic realization of multiple links of a chain is permitted as far as linearization, understood as the application of the Linear Correspondence Axiom (LCA) of Kayne (1994), can still operate. This is what happens when morphological reanalysis makes some copy invisible to the LCA. Nunes $(2001,2004)$ takes morphological reanalysis to be specifically fusion as defined by Halle and Marantz (1993), i.e. an operation that takes two sister terminal heads under a single category node and fuses them into a single terminal node. 
he bought bought he bought the car

Emphatic verb reduplication (with VPE)

(9) $[\mathrm{A}]$ a. Ele não comprou o carro, pois não?

he not bought the car, POIS NEG

'John didn't buy the car, did he?'

[B] b. Comprou comprou.

bought bought

'Yes, he DID.'

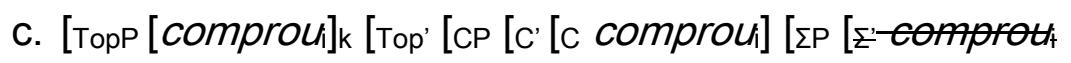

bought bought bought

[TP $\left[\mathrm{T}^{- \text {comprou }}\right.$ [VP-NULL: (O João comprou o carro $\left.\left.\left.\left.\left.\left.\left.\left.\left.)\right]\right]\right\}\right]\right]_{\mathrm{k}}\right]\right]\right]\right]$

bought the João bought the car

EP sentence-final sim structures, like verb reduplication structures, activate the domains of $\Sigma$ and C. Sentences like (10b) below are derived with verb movement to $\Sigma$ followed by movement of $\Sigma$ P to Spec,TopP. Sim is directly merged in CP. ${ }^{16}$

Elliptical sentences like (3c) above only differ from non elliptical ones because they display VP Ellipsis.

(10) [A] a. Ele não comprou o carro.

he not bought the car

'He didn't buy the car.'

[B] b. Ele comprou o carro sim. (EP and BP)

he bought the car AFF

'He did buy the car.'

\footnotetext{
${ }^{16}$ The availability of recomplementation structures like (i) below, where $\operatorname{sim}$ is sandwiched between two instances of the complementizer que (that) shows that sim is a polarity word that belongs to the CP space (cf. Laka 1990 on the difference between English yes and Spanih sí, the former a CP element, the latter a $\Sigma \mathrm{P}$ one).

(i) Ele disse que sim que vem amanhã.

$\mathrm{He}$ said that AFF that comes tomorrow

'He confirmed that he will be coming tomorrow.'
} 


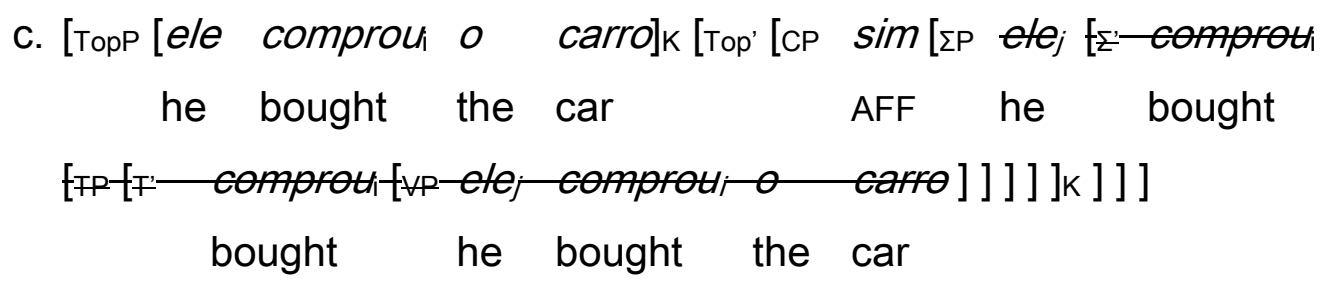

In order to syntactically express emphatic affirmation Spanish displays the si que strategy, as shown in section 2. The Spanish data (like similar data in other Romance languages) fall right into place if we take Spanish and EP to be similar in activating and giving phonological content to the functional heads $\Sigma$ and $C$ in order to express emphatic affirmation. Because $\Sigma$ is not $\mathrm{V}$-related in Spanish and therefore the verb does not move into $\Sigma$ in Spanish, it is the affirmative word síthat is externally merged in $\Sigma \mathrm{P}$, giving the $\Sigma$ category phonological content (see Laka 1990). Síthen undergoes Focus-movement, reaching CP by internal merge (cf. Battlori and Hernanz, this issue; Poletto and Zanuttini, this issue). A simplified representation of the relevant structure is given in (11-B). ${ }^{17}$

$$
\begin{aligned}
& \text { a. Juan no se compró un coche. } \\
& \text { Juan not SE bought-3SG a car } \\
& \text { 'Juan didn't buy a car.' }
\end{aligned}
$$

\footnotetext{
17 That si in Spanish and the verb in EP play a similar role in expressing emphatic affirmation is made clear by Spanish sentences like (ic) below. Although slightly marginal, a pattern with síreduplication parallels the EP verb reduplication structures (personal communication of Ricardo Etxeparre whom I am thankful to).
}
(i) [A] a. Juan no fue a Roma. Juan not went to Rome 'Juan didn't go to Rome.'
[B] b. Juan sí que fue a Roma. Juan AFF that went to Rome 'Juan did go to Rome.'
c. ?Juan sí que sí fue a Roma. Juan AFF that AFF went to Rome 'Juan did go to Rome.'




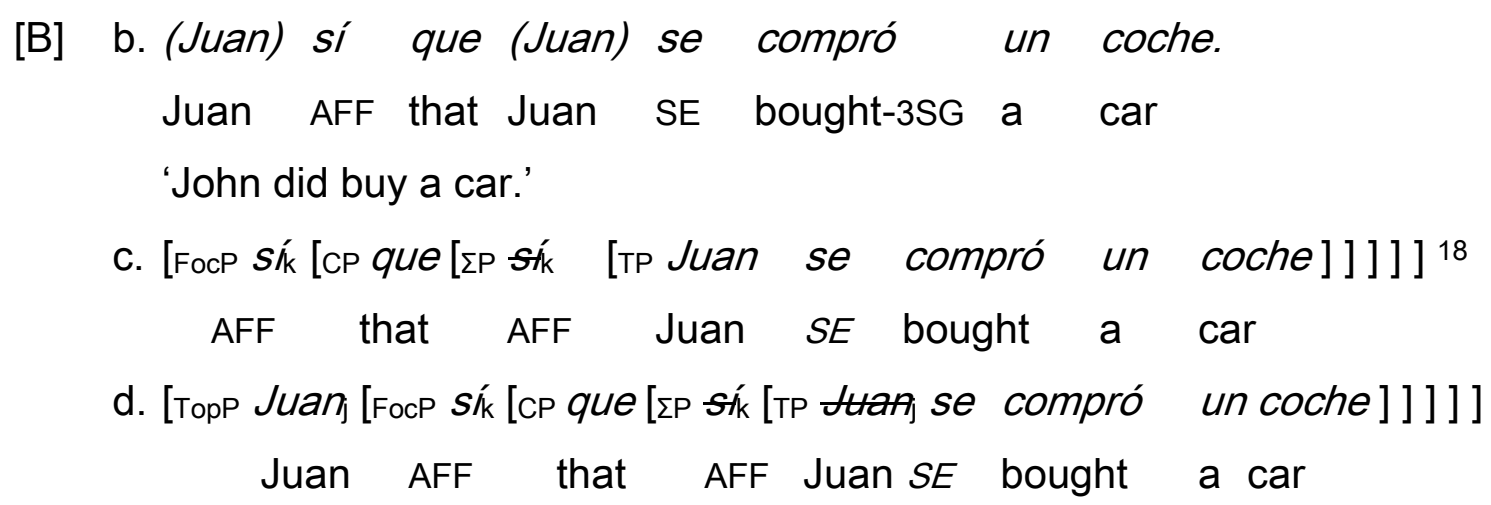

Besides the way $C$ and $\Sigma$ interact to convey emphatic affirmation, one additional trait can be observed that links up the Spanish structure in (11) with the EP structures in (8) to (10). In all the three structures expressing emphatic affirmation, a bare polar word gets focus stress and agrees in polarity value with the clausal constituent it is paired with. But while in EP the focus configuration is established through an 'extract-out-of-focus-strategy' that leaves in the sentence-final position the polarity expressing word to which unmarked focus stress is assigned, in Spanish the focus configuration usually obtains by simply moving the focused polarity word si into the left periphery (but see section 4.2 below). In European Portuguese, IPtopicalization plays in the relevant structures the role usually played in the language by object scrambling. In both cases leftward displacement of a given constituent allows another constituent to acquire prosodic and informational prominence. (see Costa 1998, 2004). In the EP sentence-final sim structures, IP-topicalization also sets the right antecedent for sim allowing its interpretation as an affirmative word. ${ }^{19}$

\footnotetext{
18 The subject can, but does not have to, be topicalized in si que sentences (against what is suggested by Brucart (1999:2836)). See on this matter Batllori and Hernanz (this issue). Both Spanish and Catalan allow the subject to intervene between que and the verb, as illustrated below with examples provided by Montse Batllori (personal communication).

(i) a. Sí que Juan le robó el libro a Sofia.(Spanish) AFF that Juan her stole the book to Sofia

b. Sí que en Joan li va robar el llibre a la Sofia. (Catalan) AFF that the Joan her goes steal the book to the Sofia 'Joan did steal the book to Sofia.'

$19 \mathrm{Sim}$ in European Portuguese is primarily an agreeing word, not an affirmative word, as attested by (i) below where sim expresses agreement with the polarity value of the preceding negative declarative or interrogative sentence.
} 


\section{Empirical evidence supporting the analysis}

In this section, it will first be shown that the mono-sentential analysis of the EP verb reduplication construction put forth in the previous section thoroughly derives all its central properties (section 4.1). Comparison with the sentence-final sim construction will be considered when appropriate. EP will then be contrasted with Spanish and Catalan so as to account for the unavailability of the verb reduplication construction in the latter, and the unavailability of the si que construction in the former. The availability in Spanish and Catalan of structures that combine si (que) with a sentence-final síwill also be accounted for (section 4.2). Brazilian Portuguese shares with EP the sentence-final sim construction but bars emphatic verb reduplication, which is in tune with the predictions of the analysis (section 4.3). Also Galician where all the three strategies to express emphatic affirmation are available lends empirical support to the approach argued for in the paper (4.4). Finally, the analysis smoothly derives the word order contrasts between confirming and denying responding assertions found in European Portuguese (section 4.5).

\subsection{Main features of the emphatic verb reduplication construction}

From 4.1.1. to 4.1.6., the main properties associated with the EP verb reduplication sentences will be described and it will be shown that such properties are in tune with the proposed analysis of EP emphatic verb reduplication. Concretely: the monosentential structure accounts for the intonation pattern and the existence of restrictions on verb reduplication (as it is not a trivial case of sentence repetition coupled with ellipsis); verb movement to $\mathrm{C}$ accounts for the incompatibility with negation, the root/subordinate asymmetry, and certain aspects of the restrictions on reduplication with respect to verbal sequences; morphological reanalysis (i.e. fusion
(i) $[\mathrm{A}]$
a. Ele não gosta da Maria.l Ele não gosta da Maria?
he not likes of-the Maria. he not likes of-the Maria?
'He doesn't like Mary.' / 'Doesn't he like Mary?'
[B] b. Sim, não gosta.
AFF not likes
'Yes, he doesn't.' 
in $\mathrm{C}$ after V-to-C takes place) accounts for the incompatibility with verb-clitic sequences, verbal complexes, and other morphologically complex constituents.

\subsubsection{Prosodic pattern: no pause; overall rising intonation}

The prosodic pattern exhibited by the sequences displaying emphatic verb reduplication supports the mono-sentential structure analysis. In fact, while sentence repetition (in a reiterative manner) would usually imply a prosodic break separating the two sentences and a falling intonation at the end of each sentence (see (12)), in verb reduplication sentences there is no prosodic break and the sequences are associated with an overall rising intonation. Sentence (14b), in contrast to (12b), is ungrammatical because a pause is imposed on the emphatic verb reduplication sentence. In (14b) the voiceless palatal realization of the dental fricative /s/ in coda position signals precisely the existence of a prosodic break. As shown in (13b), in the absence of such break, the fricative coda is realized as a voiced dental before a word-initial vowel (cf. Mateus/d'Andrade 2000).

\section{a. Eu não ando a fazer nada de mal.} I not go to do nothing of wrong 'I'm not doing anything wrong.'

[B] b. Andaff ]. Andalf ] sim. go-2SG. go-2SG AFF 'You are. Of course you are.'

(13) [A] a. Eu não ando a fazer nada de mal. I not go to do nothing of wrong 'I'm not doing anything wrong.'

[B] b. Anda[z] andalf J. [overall rising intonation] go-2SG go-2SG 'Of course you are.'

a. Eu não ando a fazer nada de mal. I not go to do nothing of wrong 'I'm not doing anything wrong.' 
[B] b. *Andaff ] andaff ]. [overall rising intonation] go-2SG go-2SG

'Of course you are.'

The prosodic patterns of the verb reduplication and the sentence-final sim constructions are similar.

4.1.2. In sequences of $\mathrm{V}[$ finite $]+V[$ non-finite $]$, only the finite verb can be reduplicated The distinction between mono-sentential verb reduplication and bi-sentential reiterative repetition can be further tested by observing their contrastive behavior with respect to sequences of a finite verb plus a non finite verb, be the finite verb an auxiliary (e.g. ser 'be') or a control verb (e.g. want 'go'). While syntactic reduplication cannot target but the finite verb (see (15b) vs. (15c) and (16b) vs. (16c)), the whole verbal sequence can be reiteratively repeated (see (15c) vs. (15d) and (16c) vs. (16d)). Reduplication of the non-finite verb alone also results in ungrammatical sentences (see (15e) and (16e))

(15) $[\mathrm{A}]$ a. Eu não fui avisada.

I not was warned 'I wasn't warned.'

[B] b. Tu foste avisada foste. you were warned were 'Of course you were warned.'

c. ${ }^{*}$ Tu foste avisada foste avisada. you were warned were warned. 'Of course you were warned.'

d. Tu foste avisada. Foste avisada. Não finjas que não. You were warned. were warned. not pretend that not 'You were warned. I'm sure you were warned. Don't pretend you were not'

e. ${ }^{*} T u$ foste avisada avisada.

you were warned warned

'Of course you were warned.' 


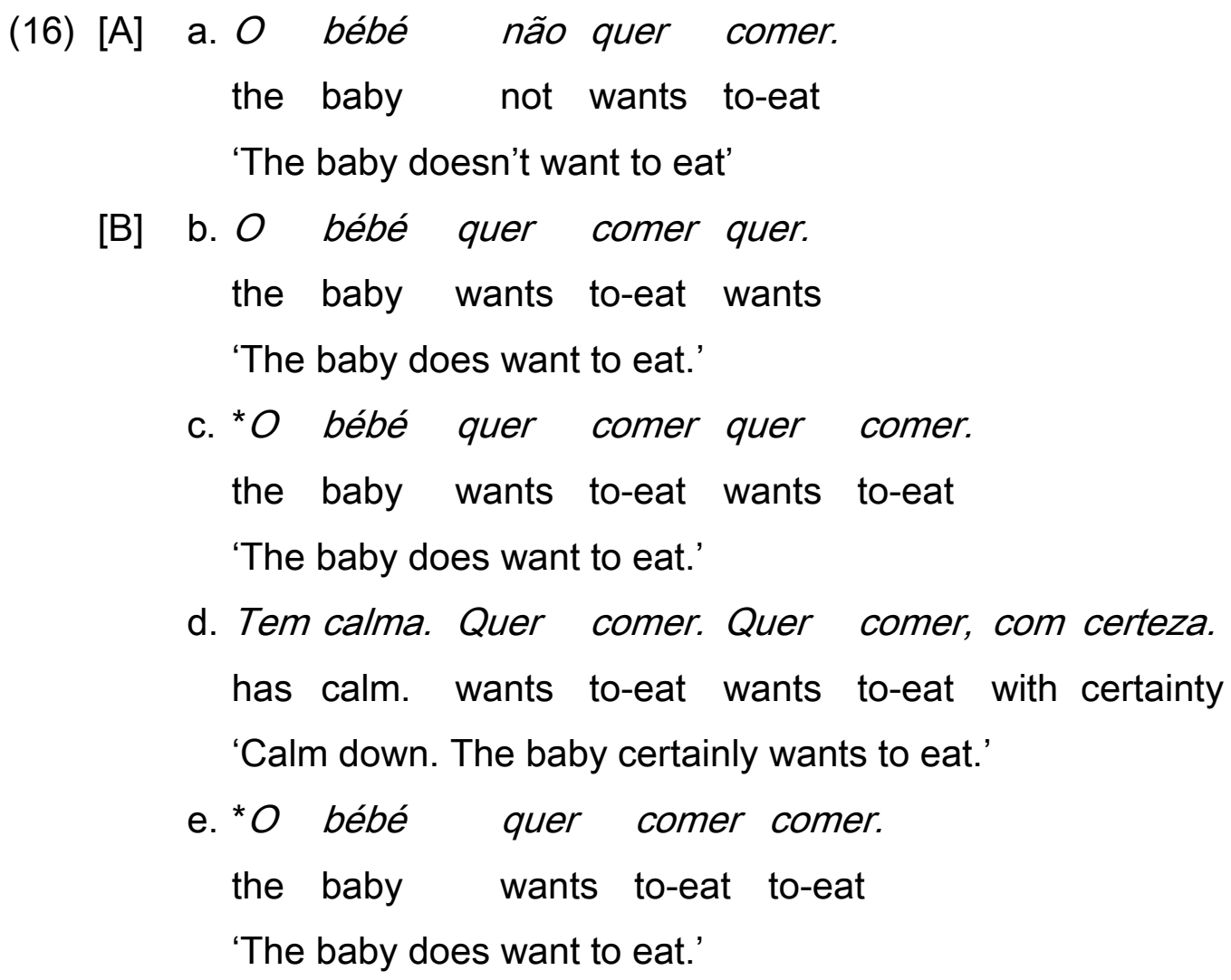

There are two types of analyses for verb sequences integrating a non-finite verb: either the two verbal heads are taken to occupy disjoint structural positions throughout the derivation (see, for example, Wurmbrand 2001) or they are taken to form a verbal complex through incorporation (see, for example, Roberts 1997). Under the former type of approach, the ungrammaticality of the (c) and (e) sentences above, in contrast to the (a) sentences, is expected because locality conditions prevent movement of the lower verbal head to $\mathrm{C}$ (in violation of the Head Movement Constraint). Under the second type of approach, the morphological complexity of the head integrating the two verbs would not allow morphological reanalysis in $\mathrm{C}$, thus preventing verb reduplication in the (c) examples.

Nunes (2004) takes as a diagnosis test to identify the operation of morphological reanalysis precisely the existence of morphological restrictions on the structures it contributes to. That is to say, morphological reanalysis (interpreted as fusion in the terms of Halle and Marantz 1993) may be blocked when complex heads are involved. This 'blocking effect' is gradual: the more complex the heads, the more constrained the availability of morphological reanalysis. Under the analysis proposed 
for verb reduplication structures in EP, we expect to find restrictions on the availability of such structures. Besides the case at point here, we will see the same pattern emerging with verb-clitic sequences (section 4.1.4) and with compounds and future/conditional forms of the verb (section 4.1.5). I will leave at an intuitive level the notion of 'morphological complexity' and will not have any insight to offer on why morphological complexity hampers and eventually blocks morphological reanalysis.

\subsubsection{Incompatibility with negation}

EP verb reduplication is a grammatical strategy to express emphatic disagreement in affirmative sentences only. Negative sentences are ungrammatical with reduplication of the verb by itself (see (17b)) or associated with the predicative negation marker (see (17c)). Because verb reduplication is distinct from sentence repetition, there is no constraint against repeating reiteratively (in a bi-sentential structure) the sequence negation marker plus verb (see (17d)).

a. $O$ João ganhou a lotaria.
the João won
'John won the lottery.'

[B] b. *O João não ganhou a lotaria ganhou.
the João not won the lottery won
c. *O João não ganhou a / otaria não ganhou.
the João not won the lottery not won
'John did NOT win the lottery.'
d. O João não ganhou a lotaria. Não ganhou, infelizmente. the João not won the lottery. not won regrettably 'John didn't win the lottery. Regrettably, he didn't.'

The exclusion of negation from emphatic verb reduplication structures is expected under the proposed analysis of verb reduplication. When the predicative negation marker não is part of the sentence, it is merged with $\Sigma_{[+n e g]}$ (Laka 1990, among others) . Given its $\mathrm{X}^{\circ}$ status, it prevents the verb from moving beyond $\mathrm{T}$, as verb movement to $\mathrm{C}$ skipping the $\Sigma$-head would violate the Head Movement Constraint. On the other hand, if the negative marker and the verb would form a complex head 
through incorporation and subsequently move to $\mathrm{C}$, morphological complexity would prevent morphological reanalysis with $\mathrm{C}$.

\subsubsection{Verb plus clitic sequences cannot be reduplicated}

Romance clitics have long been the object of debate, but no consensual results have been achieved on the grammatical mechanisms behind their placement or on their categorial nature. Relevant for our purposes here is the observation that the sequences of verb plus enclitic are not allowed in the EP emphatic verb reduplication structure. The strong ungrammaticality brought by clitics to verb reduplication sentences suggests that clitics are better characterized as minimal/maximal wordlike entities than as affix-like entities (cf. Section 4.1.5). Be it as it may, verb plus enclitic strings are instances of morphological complexity.

The examples in (18) and (19) show that the presence of a single clitic or of a clitic cluster in emphatic sentences with verb reduplication makes the sentences ungrammatical. The grammatical sentences without clitics in (18b) and (19b) are to be contrasted with the ungrammatical ones in (18c) and (19c)-(19d), which include clitics. Again this restriction on verb reduplication does not apply to reiterative sentence repetition (see (19e)). The presence of clitics in sentence-final sim emphatic sentences does not induce ungrammaticality either, which is expected given that morphological reanalysis is not at play in this case (see (18d)).

(18) $[\mathrm{A}]$ a. Não Ihe trouxeste o livro que ele te pediu. not him brought the book that he you-DAT asked 'You didn't bring him the book that he asked you.'

[B] b. Trouxe-lhe o livro que ele me pediu trouxe. bought-him the book that he me asked bought

c. ${ }^{*}$ Trouxe-Ihe o livro que ele me pediu trouxe-lhe. bought-him the book that he me asked, bought-him

d. Trouxe-lhe o livro que ele me pediu sim. bought-him the book that he me asked, AFF 'Yes, I did bring him the book he asked me.' 
(19) [A] a. Não me devolveste o livro que eu te not me returned-2SG the book that I you-DAT emprestei, pois não? lent POIS NEG

'You haven't returned me the book I lent you, did you?'

[B] b Devolvi devolvi. returned returned 'Yes, I DID.'

c. ${ }^{*}$ Devolvi-te devolvi-te. returned-you returned-you 'Yes, I DID.'

d. * Devolvi-to devolvi-to. returned-you.it returned-you.it 'Yes, I DID.'

e. Devolvi-to. Devolvi-to sim. Tenho a certeza. returned-you.it returned-you.it AFF. have-1SG the certainty 'Yes, I returned it. I certainly returned it. I'm sure about it.'

It is worth noticing that clitics are not excluded from non-emphatic answers to yes/no questions. Although answering with a bare verb, like in (20b), is more natural in EP than answering with a verb+clitic sequence, like in (20c), the two options are grammatical.

(20) [A] a. Devolveste-me o livro que te emprestei? returned-2SG-me the book that you-DAT lent-1SG 'Did you return me the book I lent you?'

[B] b. Devolvi. returned

c. Devolvi-to. returned-you.it 'Yes, (I did).' 


\subsubsection{Morphologically complex verbal forms resist reduplication}

Compound verbs like fotocopiar 'photocopy', and verbs derived with stressed prefixes such as contra (e.g. contra-atacar 'counter-attack'), make verb reduplication awkward. Both the adverb-like constituent present in the relevant compounds and the stressed prefixes are (non category changing) adjunct modifiers that left-adjoin to a word (not to the verbal root), giving rise to a complex prosodic word, i.e. a word with two word stress domains.

Examples (21) to (24) below show that verbs with stressed prefixes and compound verbs make morphological reanalysis marginal although still possible. Compare sentences (21b) and (23b), which illustrate verb reduplication with the 'simple' verbs copiar 'copy' and atacar 'attack', with sentences (22b) and (24b), displaying the more complex verbal forms fotocopiar 'photocopy' and contra-atacar 'counter-attack'.

(21) $[\mathrm{A}]$ a. Ele não copiou o livro sem autorização, pois não? he not copied the book without permission, POIS NEG 'He didn't copy the book without your permission, did he'?

[B] b. Copiou copiou.

copied copied

'Yes, he DID.'

(22) [A] a. Ele não fotocopiou o livro sem autorização, pois não? he not photocopied the book without permission, POIS NEG 'He didn't copy the book without your permission, did he?'

[B] b. ??fotocopiou fotocopiou.

Photocopied photocopied

'Yes, he DID.'

(23) $[\mathrm{A}]$ a. Ele não atacou 0 candidato, pois não? he not attacked the candidate POIS NEG 'He didn't attack the candidate, did he?' 
[B] b. Atacou atacou.

Attacked attacked

'Yes, he DID.'

(24) $[\mathrm{A}]$ a. $O$ candidato não contra-atacou, pois não?

the candidate not counter-attacked, POIS NEG

'The candidate didn't counter-attack, did he?'

[B] b. ??Contra-atacou contra-atacou.

counter-attacked counter-attacked

'Yes, he DID.'

Future and conditional forms have a similar effect on verb reduplication sentences as compound and compound-like verbs. EP futures and conditionals are the only verbal forms that allow mesoclisis, which indicates that futures and conditionals have a particular morphological structure among verbal forms (cf. Roberts 1992; Roberts \& Roussou 2002, 2003; Duarte \& Matos 2000; Oltra-Massuet \& Arregui 2005) . As illustrated in (25a) and (25c) clitics are in general enclitics in matrix clauses in EP, surfacing adjacent to the right edge of the verbal form (i.e. to the agreement morphemes). When a future or conditional form of the verb occurs in a matrix clause, however, the clitic surfaces preceding the sequence formed by the tense morpheme (present or past) plus the agreement morpheme (see (25b) and (25d)). The sentences in (26)-(27) below, to be contrasted with (28), show that future and conditional forms of the verb are not unproblematic in emphatic verb reduplication structures.
a. Ele ataca-o
se puder.
he attack-PRESENT-INDICATIVE-him if
can 'He will attack him if he can.'
b. Ele atacá-lo-á se puder. he attack-him-will/[T(present)+Agr morphemes] if can 'He will attack him if he can.'



c. Ele atacava-o
se pudesse.
he attack-IMPERFECT-INDICATIVE-him if could
'He would attack him if he could.'
d. Ele atacá-lo-ia se pudesse.
He attack-him-will/[T(past)+Agr morphemes] if could
'He would attack him if he could.'

(26) $[\mathrm{A}]$ a. Ele não atacará 0 candidato, pois não? he not attack-will the candidate POIS NEG 'He will not attack the candidate, will he?
[B] b. ??Atacará atacará.
attack-will/[T+Agr morphemes] attack-will/[T+Agr morphemes] 'Yes, he WILL.'

(27) $[\mathrm{A}]$ a. Ele não atacaria 0 candidato, pois não? he not attack-would the candidate POIS NEG 'He would not attack the candidate, would he?
[B] b. ??Atacaria atacaria. attack-would/[T+Agr morphemes] attack-would/[T+Agr morphemes] 'Yes, he WOULD'

(28) $[\mathrm{A}]$ a. Ele amanhã não ataca o candidato, pois não? he tomorrow not attack the candidate POIS NEG 'He will not attack the candidate tomorrow, will he?
[B] b. Ataca ataca. attack-PRESENT-INDICATIVE attack-PRESENT-INDICATIVE 'Yes, he WILL.'

Nunes (2004) shows that grammatical marginality increases in a gradual way as morphological complexity grows. Nunes' observation is confirmed by the data we are discussing. As a matter of fact, when a compound or a compound-like verb displays future or conditional morphology, a cumulative effect arises with the result that the verb reduplication structure becomes ungrammatical. This is exemplified with the 
prefixed verb contra-atacar 'counter-attack' in (29), and with the compound verb fotocopiar 'photocopy' in (30). Sentences (29c) and (30c) show once more that the emphatic sentence-final-sim sentences, which do not involve morphological reanalysis, are exempt from morphological restrictions

(29) $[\mathrm{A}]$ a. $O$ candidato não contra-atacará, pois não? the candidate not contra-attack-will POIS NEG 'The candidate will not contra-attack, will he?'

[B] b. * Contra-atacará contra-atacará. contra-attack-will/[T+Agr morphemes] contra-attack-will/[T+Agr]

c. Contra-atacará $\operatorname{sim}$. contra-attack-will/[T+Agr morphemes] AFF 'Yes, he WILL.'

(30) $[A]$

a. Ele não fotocopiaria o livro sem a. tua he not photocopy-would the book without the your autorização, pois não? permission, POIS NEG 'He wouldn't photocopy the book without your permission, would he?'

[B] b. *Fotocopiaria photocopy-would/[T+Agr morphemes]

c. Fotocopiaria

photocopy-would/[T+Agr morphemes] AFF 'Yes, he WOULD.' fotocopiaria. photocopy-would/[T+Agr] sim.

\subsubsection{Emphatic verb reduplication is a root phenomenon}

The ungrammatical sentence (31c), to be contrasted with the well-formed (31b), shows that emphatic verb reduplication is blocked in subordinate clauses. Hence, in complex sentences the matrix verb can display reduplication while the embedded verb cannot, as illustrated by the contrast between (32b) and (32c). ${ }^{20}$

\footnotetext{
${ }^{20}$ All types of subordinate clauses exclude verb reduplication. Some additional examples are given below.

(i) a. "Ele está preso porque roubou o carro roubou.
} 
(31) $[\mathrm{A}]$ a. Ele não ouve bem.

he not hears well

'He doesn't hear well.'

[B] b. Ele ouve bem ouve.

he hears well hears

'He does hears well.'

c. *Eu sei que ele ouve bem ouve.

I know that he hears well hears

'I know that he does hear well.'

(32) $[A]$

a. Não sei se ele vem à festa.

not know-1SG whether he comes to-the party

'I don't know whether he is coming to the party.'

[B] b. Sabes selque ele vem à festa sabes.

know-2SG whether/that he comes to-the party know-2SG

'You do know whether/that he is coming to the party'

c. *Sabes que ele vem à festa vem.

know-2SG that he comes to-the party comes

'You know that he WILL come to the party.'

This root/subordinate contrast is reminiscent of the root/subordinate asymmetry found in (asymmetric) V2 languages and can be accounted in a similar way, crucially

he is in-jail because stole the car stole

'He is in jail because he did steal the car.'

b. *Ele não me falou quando me viu no cinema viu.

he not me spoke when me saw in the cinema saw

'He didn't say hello when he ran into me in the cinema.'

b. *Ele não me falou embora me tenha visto no cinema tenha.

he not me spoke although me have seen in the cinema have

'He didn't say hello although he did see me in the cinema.'

d. *Se fizer sol fizer, vamos à praia.

if appears sun appears go-1PL to-the beach

'We will go to the beach if the sun does show up.' 
invoking verb movement to $\mathrm{C}$, which subordinate clauses typically make unavailable. It must be noted however that sentence-final sim sentences are also subject to the root/subordinate asymmetry, although their exclusion from subordinate clauses seems weaker than the ungrammaticality of verb reduplication. This is illustrated in (33) below. As sentence-final sim sentences do not involve verb movement to C, there must be another explanation for their confinement to root domains. An hypothesis for future investigation is that denials (i.e. reversing responding assertions in the context of a previous assertion) may correspond to a particular clause-typing codified by an abstract feature that belongs to root-Comp.

[A] a. Ele não vem à festa.
he not comes to-the party
'He isn't coming to the party.'
[B] b. ???Acabaram de me dizer que ele vem à
finished-3PL of me-DAT say-INF that he comes to the
festa sim.
party AFF dizer que ele vem à
c. *Acabaram de me of me-DAT say-INF that he comes to-the
finished-3SG of
festa vem.
party comes
'I was just told that he WILL come to the party.'

\subsection{Contrasting European Portuguese with Spanish and Catalan}

Taking the pattern of minimal affirmative answers to yes/no questions as the crucial test to establish whether a particular language has verb movement to $\Sigma$ or not, we observed in section 3 that Spanish does not allow bare verb answers to yes/no questions, which indicates that it does not license autonomous movement of $V$ to $\Sigma .21$ Under our starting hypothesis that languages lacking verb movement to $\Sigma$ disallow emphatic verb reduplication, we thus rightly predict that Spanish will have to resort to some other option(s). Catalan and Italian are, in this respect, like Spanish,

\footnotetext{
${ }^{21}$ Of course the verb can move through $\Sigma$ on its way to higher functional categories. It may also be the case that the verb is attracted to $\Sigma$ by particular polar items merged in $\Sigma P$ (cf. Laka 1990).
} 
as illustrated below with Catalan data. The examples in (34) and (35) show, respectively, that Catalan does not allow bare verb answers to yes/no questions and, concomitantly, excludes emphatic verb reduplication. Catalan resorts instead to the si que construction (see Poletto and Zanuttini, this issue, for comparable Italian data).

Catalan

(34) $[\mathrm{A}]$

a. ¿Sopa aquí en Joan? dines here the Joan 'Does Joan dine here?'

[B] b. * Sopa.

dines-3SG

C. Sí.

AFF

'Yes, he does.'

(35) [A] a. En Joan no sopa aquí els dijous.

the Joan not dines here the Thursdays

'Joan doesn't dine here on Thursdays.'

[B] b. * Sopa aquí sopa.

Dines here dines

c. Sí que sopa aquí.

AFF that dines here

'He certainly does.'

The proposed structural analysis of sentence-final sim denials found in European Portuguese also includes verb movement to $\Sigma$ (see (10) above). At first glance, this seems to imply that sentence-final sishould be barred in the Romance languages that lack verb movement to $\Sigma$. These languages, however, have an alternative way to license strong $\Sigma$ (i.e. $\Sigma^{*}$ ), through external merge of the word sí, which allows sentence-final sísentences to actually be derived. The examples in (36)-(37) below indicate that the relevant structures are derived in Spanish and Catalan with the concurrence of two independent AFF words phonologically expressed as sí. One of 
them is the $\Sigma$-word that appears in the si que construction, the other is an external si directly merged in the outer layer of CP. It appears in sentence-initial position if the constituent containing "sí (que)" does not undergo topicalization, as in (36a).

Topicalization may place the external síin sentence-final position, as in (36b-c) and (37). ${ }^{22}$ The sentences with sentence-final sim/sibear resemblance with the double negation sentences that will be discussed in section 5.23

\author{
(36) a. Sí, sí que llueve. (Spanish. Google search) \\ AFF AFF that rains \\ b. Sí que llueve sí. (Spanish. Google search) \\ AFF that rains AFF \\ c. Sí que plou, sí. (Catalan. Google search) \\ AFF that rains AFF \\ 'It does rain.'
}

22 The examples in (37) were kindly provided by Montse Batllori (personal communication).

${ }^{23}$ Because this study is centered on European Portuguese, not on Spanish and Catalan, I do not discuss here whether the lower sí in sentences (36)-(37) has moved to $C$ (even if the presence of que suggests so). For further details on the Spanish and Catalan data, see Batllori and Hernanz, this issue. For details on Italian, See Poletto and Zanuttini, this issue. Italian also allows sentence-final sì sentences (see (i) below) but in Italian there is no repetition of $s i$. This fact suggests that the Italian sentences include one single si item and are derived with movement of si from $\Sigma \mathrm{P}$ to $\mathrm{CP}$, followed by IP-topicalization.

(i) [A] Non ha comprato un'auto rossa, vero? (example provided by a reviewer) not has bought a car red true

'He didn't buy a red car, did he?'

[B] L' ha comprata si .

it has bought AFF

'He did buy it.'

I have no account to offer with respect to the difference between Italian, on the one hand, and Spanish and Catalan, on the other, relative to the structures with sentence-final sí/si . As will be referred in footnote (24) below, Italian si does not strictly pattern with Spanish and Catalan sí in the context of polar question-answer pairs. It should also be noted that sentence-final $s i$ is not accepted by all Italian speakers, although it is widespread across Italy (according to Cecilia Poletto, personal communication; one of the reviewers, on the other hand, signals this construction as belonging to central/southern Italian). Variation in the acceptability of sentence-final si in Italian contrasts with the universal availability of sentence-final sim for speakers of European and Brazilian Portuguese. 


(37) a. Sí (que) ha cantado la soprano, sí. (Spanish)
AFF that has sung the soprano AFF
b. Sí que ha cantat la soprano, sí. (Catalan)
AFF that has sung the soprano AFF
'The soprano did sing.'

We have an explanation for why most Romance languages disallow emphatic verb reduplication (such languages do not have verb movement to $\Sigma$ ) and are also able to account for the widespread availability of sentence-final sim/sisentences (it mainly depends on the availability of IP-topicalization, or topicalization of some layer of the $\mathrm{CP}$, whereas each language resorts to its own ways to license $C$ and $\Sigma$ ). We still need to elucidate why European Portuguese excludes the si que strategy found in most Romance languages. My proposal is that this is the effect of a lexical contrast: while the word sim in Portuguese is a C-word (directly merged in CP), si in Spanish, Catalan and other Romance languages is of two types, either a $\mathrm{C}$-word or a $\Sigma$-word (first merged in $\Sigma \mathrm{P}$ ). Because EP sim must be externally merged in $\mathrm{C}$, it does not satisfy the requirement imposed by emphatic affirmation structures that $\Sigma$ be given phonological content. This is why sentence-final sim sentences in European Portuguese still require verb movement to $\Sigma$. Only Spanish si and similar $\Sigma$-words in other Romance languages can play the same role as the verb in European

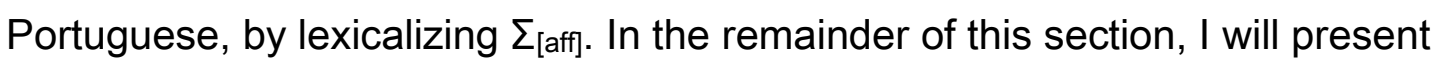
empirical evidence supporting the view that EP sim is grammatically distinct from Spanish and Catalan si. ${ }^{24}$

\footnotetext{
${ }^{24}$ Comparison will be here restricted to European Portuguese versus Spanish and Catalan with the goal of understanding why European Portuguese excludes the si que strategy. One of the reviewers notes that (central/southern) Italian síbehaves in some respects (but not in others) like EP sim, although Italian patterns with Spanish and Catalan as for displaying the si que construction (e.g.: like EP sim, Italian si does not constitute alone an appropriate answer to a negative polar question; nevertheless, like Spanish sí, Italian si can by itself deny a negative statement). Other reviewer refers that sim does not have exactly the same properties in European Portuguese and Brazilian Portuguese. The reviewers' comments indicate the need for a thorough comparative investigation into the grammatical behavior of the cognate sim/si/si words of the Romance varieties. This task goes well beyond the scope of the current paper.
} 


\subsubsection{Answers to negative questions}

The examples in (38) to (40) below illustrate the incapacity of Portuguese sim to constitute by itself an affirmative answer to a negative question (see (38b)) in contrast to Spanish and Catalan sí(see (39b)-(40b)). In Portuguese (both European and Brazilian Portuguese) only the verb can, alone, set an appropriate affirmative answer to a negative yes/no question, as shown by the contrast between (38b) and (38c).

European Portuguese

(38) $[\mathrm{A}]$

a. O João hoje não vai ao cinema? the João today not goes to-the cinema 'Isn't John going to the movies today?'

[B] b. * Sim.

AFF

'Yes, he is going to the movies today.'

c. Vai.

goes

'Yes, he is going to the movies.'

Spanish

(39) $[\mathrm{A}]$

a. No va a ir al cine hoy Juan?

not go to go to-the cinema today Juan 'Isn't John going to the movies today?'

[B] b. Sí. (= Sí, Juan va a ir al cine hoy.) AFF (= AFF Juan goes to go to-the cinema today) 'Yes, he is going to the movies today).'

Catalan

(40) $[\mathrm{A}]$
a. Avui no anirà al cine
en Joan?
today not will-go to-the cinema the Joan
'Isn't John going to the movies today?' 

[B] b. Sí. (=Sí, en Joan anirà al cine avui.) AFF (= AFF the Joan will-go to-the cinema today) 'Yes, he is going to the movies today.'

Behind the observed empirical contrast lies the different nature of the affirmative words available in Portuguese, on the one hand, and in Spanish and Catalan, on the other. Being a CP-element, Portuguese sim licenses a null IP $(=\Sigma P)$ whose content is recovered from the preceding yes/no question. ${ }^{25}$ What makes the situation different in Spanish and Catalan is the fact that sí in these languages is an affirmative $\Sigma$-word. As the affirmative word síis merged in $\Sigma \mathrm{P}$, the null constituent that sílicenses is not the full IP $(=\Sigma P)$, but a smaller chunk of structure, presumably TP, the complement of $\Sigma$. So in Spanish and Catalan the polarity value of the answering clause is strictly established by síbecause the null constituent whose content is recuperated from the question does not include the polarity encoding head $\Sigma .{ }^{26}$

\subsubsection{Answers to embedded questions}

Because sim-answers are interpreted by recovering their antecedent as a whole (to be more precise, the full IP above which sim is structurally placed), they are unable to be interpreted as replies to embedded questions. In this respect, Portuguese sim behaves quite differently from the affirmative word si in Spanish or Catalan, as in the latter sícan constitute a reply to an embedded question. While an answer with sí is associated with two possible interpretations in Spanish and Catalan (see (42b)(43b)), an answer with sim in Portuguese is unambiguously interpreted as a positive answer to the main question. Only the verb can constitute a minimal affirmative

\footnotetext{
${ }^{25}$ I am here adopting the analysis devised by Holmberg $(2003,2005)$ who deals with similar facts in English:

(i) a. - Does John speak French? - Yes. / - Yes, he does.

b. - Doesn't John speak French? - *Yes. / - Yes, he does.

(Examples taken from Holmberg 2003:111)

${ }^{26}$ The fact that in Italian a minimal answer with si is not acceptable in the context of a negative polar question (as pointed out in footnote 24 ) suggests that being a $\Sigma$-word is a necessary condition to be appropriate in the relevant context, but not a sufficient one.
} 
answer to the embedded question. This is exemplified with the contrast between (41b) and (41c).

\section{European Portuguese}

(41) $[A]$

a. Sabes se o João foi à festa? know-2SG if the João went to-the party 'Do you know if John went to the party?'
[B] b. Sim. (= 'Sim, sei.'/ *'Sim, foi.')
AFF (= AFF know-1SG / *AFF went-3SG)
'Yes, I do.' / *'Yes, he did.'
c. Foi. (= 'Sim, foi.')
went-3SG (= AFF went-3SG)
'Yes, he did.'

Spanish

(42) $[\mathrm{A}]$
a. ¿Sabes
si Juan fue
a la fiesta?
know-2SG if Juan went to the party

'Do you know if John went to the party?'
[B] b. Sí. (=Sí, lo sé. I=Sí, Juan fue a la fiesta.) AFF (= AFF it know-1SG $/=$ AFF Juan went to the party) 'Yes, I know (that he did).' / 'Yes, he did.'

\section{Catalan}

(43) $[\mathrm{A}]$

a. Saps si en Joan va.anar al cine? know-2SG if the Joan went to-the cinema 'Do you know if John went to the movies?'

b. Sí. (=Sí, ho sé. I=Sí, en Joan va.anar al cine.) AFF (= AFF it know / = AFF the Joan went to-the cinema) 'Yes, I know (that he did).' / 'Yes, he did.'

The examples in (42) and (43) above show that the affirmative $\Sigma$-word si of Spanish and Catalan can be interpretatively associated with the polarity-encoding $\Sigma$ projection at two different levels, namely, the matrix $\Sigma \mathrm{P}$ or the embedded $\Sigma \mathrm{P}$, thus 
licensing and recuperating the content of a larger or smaller null constituent. The contrast between (42)-(43) and (41) makes clear that the Portuguese affirmative word sim, on the other hand, behaves as a root-Comp element that cannot be associated with so internal a position as the functional space of the embedded clause. Thus sim always licenses and recuperates the content of the matrix IP present in the question. ${ }^{27}$

\subsubsection{Denial of a negative statement}

In Spanish, sícan by itself contradict/correct a previous negative statement, as illustrated by (44) below. This is impossible in Portuguese where affirmative declaratives expressing denial necessarily include the verb.

Spanish

$$
\begin{aligned}
& \text { a. Juan no fue a Roma. } \\
& \text { Juan not went to Rome } \\
& \text { 'John didn't go to Rome.' }
\end{aligned}
$$

[B] b. Sí.

'(You are wrong,) he did go to Rome.'

A particular intonation is associated with (44b) as only a long high-low sí expresses the intended meaning (personal communication of Ricardo Etxeparre). ${ }^{28}$

\footnotetext{
${ }^{27}$ Two facts seem, at first glance, to point toward opposite directions with respect to EP sim. First, sim can express negative agreement if it is associated with a verbal tag that clarifies its meaning (see footnote 19). Second, $\operatorname{sim}$ can contribute to express positive disagreement, that is, emphatic affirmation, in which case it occurs in final position. While the former fact indicates that polarity sim is basically an agreeing word (not an inherently affirmative word) whose content must be established by its antecedent, the latter fact appears to contradict this conclusion. The contradiction is only apparent, though. Whereas the antecedent of sentence-initial sim is the preceding interrogative sentence, the antecedent of sentence-final sim is the topicalized constituent co-occurring with sim within the same sentence. In this case, sim reinforces the assertive meaning of its sentence-bound antecedent.

${ }^{28} \mathrm{~A}$ similar observation is offered with respect to Italian by one of the reviewers: "in Italian, the denial of a negative statement can be a long high-low si ". The reviewer provides the following example:
(i) $[\mathrm{A}]$
Giann
non è
andato a
a Roma.
Gianni not is gone
to Rome
'Gianni didn't go to Rome.' 
A short flat si would instead be interpreted as a manifestation of agreement with the interlocutor (i.e. as 'you are right, he didn't go to Rome'). The intonation contrast presumably signals a structural difference. I take (44b) to be derived with movement of síto the CP domain, according to the general derivational pattern of emphatic affirmative declaratives. It can then work as a polarity-reversal operator just like French si (cf. Holmberg 2003:112) So, although síin (44b) licenses a null IP whose content is recuperated from the proposition in (42a), there is no clash between affirmative siand the negative value of $\Sigma$ in (44a). As Holmberg puts it, having in mind French, ${ }^{29}$ síneutralizes the contextually set negative feature of $\Sigma$ [= Pol in Holmberg], by deleting it, and assigns the value affirmative to $\Sigma$. What makes Portuguese sim unable to play the same role as Spanish síin a denial context such as the one illustrated in (44) above is the fact that it is not the right kind of entity, namely a $\Sigma$-word.

\subsection{Contrasting European Portuguese with Brazilian Portuguese}

Brazilian Portuguese (BP) displays like European Portuguese bare verb answers to yes/no questions, as illustrated in (45). Nevertheless, it does not permit emphatic verb reduplication, resorting only to the sentence-final sim strategy to express positive denial, as exemplified in (46). So the data in (45)-(46) show that the availability of unmarked verbal answers to yes/no questions does not necessarily correlate with the availability of the verb reduplication strategy. Brazilian Portuguese allows the former but disallows the latter. Since according to our analysis verb movement to $\mathrm{C}$ is a crucial step in the derivation of the EP verb reduplication

[B] a. Si ì ì ì , (c'è andato). ["You are wrong”]

AFF (there is gone)

'Yes, he did go.'

b. No. ["You are right"]

no

'No, he didn't.'

29 Holmberg (2003) considers also Swedish, German and Finnish. All these languages differ from the Romance languages studied in this paper in that they resort to a specific affirmative word to express denial. French, for example, has si which denies a proposition (or a presupposition) present in the discourse context and oui which instead expresses agreement with a previous statement (or presupposition) or else constitutes a neutral affirmative answer to a yes/no question. 
structures, the unavailability of such structures in BP is correctly predicted, because BP lacks verb movement to $\mathrm{C}$ (a point to which we will return shortly). Putting together the Spanish/Catalan and the BP facts, the proposed analysis is neatly supported: Spanish and Catalan fail to derive the EP type of verb reduplication because these languages lack verb movement to $\Sigma$, although both Spanish and Catalan are consensually described as having verb movement to $\mathrm{C}$. Brazilian Portuguese, on the other hand, has verb movement to $\Sigma$ (so it licenses bare verb polar answers) but not verb movement to $\mathrm{C}$ and this is why it also fails to derive emphatic verb reduplication sentences.

Brazilian Portuguese

(45) $[\mathrm{A}]$ a. Você também vai pra Minas? you also go to Minas

'Are you also going to Minas?'

[B] b. Vou.

go-1SG

'Yes, I am.'

(46) $[\mathrm{A}]$ a. Você não vai pra Minas, vai? you not go to Minas go

'You are not going to Minas, are you?'

[B] b. Eu vou pra Minas sim. I go-1SG to Minas AFF

c. Vou sim. go-1SG AFF

d. *Eu vou pra Minas vou. [with overall rising intonation] I go-1SG to Minas go-1SG

e. *Vou vou. [with overall rising intonation] go-1SG go-1SG 'Of course l'm going to Minas.'

Among Brazilian linguists, it is consensually assumed that BP lacks verb movement to C (see Kato and Roberts 1996, among others). The absence of verb 
movement to $C$ in BP is the source for the word order facts illustrated by (47) to (50) below. In contrast with European Portuguese, Brazilian Portuguese systematically disallows subject-verb inversion when the order verb-subject is the outcome of verb movement to C. This is the case of root interrogatives (see (47) and cf. Ambar 1992, Kato 2004), of gerund clauses (see (48) and cf. Ambar 1992, Britto 1998, Lobo 2003), of root conditional or future interrogatives with a wonderinterpretation (see (49) and cf. Ambar 1992), and of root subjunctives like (50), which are just unattested in Brazilian Portuguese.

a. Quem disse a Maria que telefonou?
who said the Maria that called
'Who did Maria tell that called?'
b. Quem a Maria disse que telefonou?
who the Maria said that called
'Who did Maria tell that called?'

(48) a. Telefonando a Maria, saímos para jantar. EP: OK/ BP: * calling the Maria leave-1PL for dinner 'As soon as Maria calls, we will go out for dinner.'
b. A Maria telefonando, saímos para jantar. EP: * / BP: OK the Maria calling leave-1PL for dinner 'As soon as Maria calls, we will go out for dinner.'

(49)
a. Teria/terá $0 \quad Z$ Zé encontrado as chaves? EP: OK / BP: * would-/will-have the Zé found the keys 'I wonder whether Zé could find his keys.'
b. Ele teria/terá encontrado as chaves? EP: OK / BP: OK he would/will-have found the keys
'I wonder whether he could find his keys.'
(50) Soubesse
o rato as intenções do
gato know-IMPERF-SUBJ-3SG the mouse the intentions of-the cat e teria escapado.
EP: OK / BP:* 
and would-have escaped

'If the mouse knew the intentions of the cat, it would have escaped.'

4.4. The different strategies are not grammatically incompatible: the case of Galician It has been argued up to this point that verb movement in relation to the functional heads $\Sigma$ and $\mathrm{C}$ determines whether the verb reduplication strategy to express emphatic affirmation might be available in a particular language. Only languages that have both verb movement to $\Sigma$ and verb movement to $C$ allow emphatic verb reduplication. ${ }^{30}$ The sentence-final sim/sístrategy, on the other hand, is found in all the Romance languages discussed in this paper although it does not quite correspond to the same structure across languages (see section 4.2 and footnote 23 above). As for the si que strategy, it was proposed that its availability does not depend on verb movement but on the existence of an appropriate type of affirmative polar word in the language. If this line of reasoning is on the right track, we expect that nothing in principle will prevent the co-occurrence of the three different strategies in the same grammar. In particular it is expected that verb reduplication and sí que structures do not show complementary distribution across languages, thus might be available in the same grammar. Galician demonstrates that this is in fact so as verb reduplication, si que and sentence-final siare all allowed in the language:

\section{Galician}

(51) $[A]$

a. Aníbal non sabe destes assuntos.

Aníbal not knows of-these matters

'Aníbal doesn't know of such matters.'

[B] b. Aníbal si que sabe destes assuntos. ${ }^{31}$ [sique]

Aníbal AFF that knows of-these matters

\footnotetext{
30 Note that these are necessary conditions but might be not sufficient.

${ }^{31}$ Like in Spanish, the complementizer que is optional in Galician in the si que construction. So an alternative to (51b) above is (i) below:
}

(i) Anibal si sabe destes assuntos.

Anibal AFF knows of-these matters

'Anibal does know of such matters.' 


c. Aníbal sabe destes assuntos sabe. [verb reduplication]
Aníbal knows of-these matters knows
d. Aníbal sabe destes assuntos si.
Aníbal knows of-these matters AFF
'Aníbal does know of such matters.'

The coexistence of (51b) and (51d) shows that si in Galician is of two types: either a C-word like Portuguese sim or a $\Sigma$-word like Spanish/Catalan (lower) sí. Independent empirical evidence supporting the view that Galician siand Portuguese sim are not grammatically coincident comes from clitic placement and tag-questions formation.

Clitic placement is similar in Galician and European Portuguese. These languages diverge from all the other Romance languages in that enclisis surfaces in finite clauses. Proclisis surfaces in finite clauses as well but it depends on the presence of certain elements, referred to as 'proclisis-triggers', in preverbal position. Negation, subordinators, quantifiers, wh-phrases and certain adverbs qualify as proclisistriggers in European Portuguese and Galician as well. The interesting fact about si/sim is that in Galician simay play the same role as predicative negation in triggering proclisis whereas in European Portuguese sim only permits enclisis, as illustrated below. In (52) o/lo is the accusative clitic, in (53) me is the dative clitic.

Galician

a. ¿Díxenche que marcho mañá? told-1SG-you-DAT that leave-1SG tomorrow Probablemente non o dixen. probably not it-ACC told.

'Did I tell you I'm leaving tomorrow? Probably I didn't.'
[B] b. Si, dixéchelo.
[Enclisis with $s]$
AFF said-2SG-it-ACC
C. Si 0 dixeches.
[Proclisis with s]
AFF it-ACC said-2SG
'Yes, you did.' 

d. Non, non 0 dixeches.
[Proclisis with non]
No, not it-ACC said-2SG
e. *Non, non dixechelo.
[ Enclisis with non]
No, not said-2SG-it-ACC
'No, you didn't.'

Portuguese

(53) $[\mathrm{A}]$
a. Disse-te
que me
vou
embora
amanhã?
told-1SG-you-DAT that myself go-1SG away tomorrow

Provavelmente não disse.

probably not told.

'Did I tell you I'm leaving tomorrow? Probably I didn't.'

[B] b. Sim, disseste-me.

[Enclisis with sim]

AFF told-2SG-me-DAT

c. * Sim me disseste.

$\left[{ }^{*}\right.$ Proclisis with $\left.\operatorname{sim}\right]$

AFF me-DAT told-2SG

'Yes, you did.'

d. Não, não me disseste.

[Proclisis with não]

no not me-DAT told-2SG

e. *Não, não disseste-me.

[Enclisis with não]

No not told-2SG-me-DAT

'No, you didn't.'

Comparing Galician with European Portuguese is also illuminating when we look at tag questions. In Galician and European Portuguese tag questions presupposing an affirmative answer are made up of an affirmative clause, an interrogative-negative word (phonologically akin to the negation marker) and a verbal form that repeats the main verb or the finite auxiliary of the affirmative clause. I take the affirmative clause to be a topic merged in Spec,TopP, the interrogative-negative word to be inserted in Spec,CP, and the inflected bare verb in the tag to be incorporated in $\Sigma$, licensing VPellipsis. In tandem with sentences like (54a), Galician also allows sentences like (54b) which European Portuguese excludes. The difference between (54a) and (54b) is just that in the former $\Sigma$ is filled with the verb while in the latter it is filled with the 
affirmative word si. ${ }^{32}$ European Portuguese cannot derive tag questions like (54b) since an affirmative $\Sigma$-word is not available in Portuguese, as the grammaticality contrast between (54b) and (55b) reveals.

Galician

(54)
a. ¿Este meniño é o neto de Carmela, non é? this kid is the grandson of Carmela, NEG is
b. ¿Este meniño é o neto de Carmela, non si? this kid is the grandson of Carmela, NEG AFF
'This little boy is the grandson of Carmela, isn't he?'
(Galician examples taken from Álvarez and Xove 2002: 199)

\section{European Portuguese}

(55)

a. Este menino é o neto da Gabriela, não é?
this kid is the grandson of-the Gabriela, NEG is
b. *Este menino é o neto da Gabriela, não sim?
this kid is the grandson of-the Gabriela, NEG AFF
'This little boy is the grandson of Gabriela, isn't he?'

4.5. Contrasting emphatic with non-emphatic responses in European Portuguese European Portuguese offers clear evidence that syntax deals with the distinction between confirming answers and denials (i.e. reversing reactions to a statement, which can be associated with a tag question). To be more precise, by observing the European Portuguese data we know that the relevant distinction is syntactically expressed in natural language although there is room to admit that not all languages

\footnotetext{
32 The correlate in Catalan of the Galician "no si?' tags are "¿no que si?' tags (see (i) below). Catalan makes clear that the interrogative-negative word no occurs in the CP domain. Tag-questions with "¿no que sí?' (¿no that AFF?) are ungrammatical in Spanish, but "¿verdad que si??' (¿true that AFF?) is a possible tag in Spanish. Neither type of tags with sí is allowed in European Portuguese. Catalan

(i) En Joan va.comprar el cotxe, \{¿no que sí? / ¿veritat que sí? / ¿oileh que sí?\} the Joan bought the car, \{¿no that AFF? / ¿true that AFF? / ¿INTERJ that AFF?\} 'Joan is buyng a car, isn't he?'
} 
resort to syntax to express it. ${ }^{33} \mathrm{~A}$ salient syntactic manifestation of the relevant distinction in European Portuguese is word order. The word sim occurs in sentenceinitial position in unmarked affirmative answers, that is to say, in confirming answers, but in sentence-final position in denying reactions. ${ }^{34}$ This is illustrated in (56)-(57). According to the analysis argued for in this paper, the opposite word orders shown in (56) versus (57) arise because IP-topicalization is part of the derivation of emphatic affirmative structures only. In sim denying reactions, IP-topicalization has the effect of creating the sentence-bound antecedent that determines the interpretation of sim. At the same time, it places sim in a prosodically prominent position.

A] a. Ele comprou o carro verm
he bought the car red
'Did he buy the red car?'
B] b. Sim, comprou.
AFF bought
'Yes, he did.'
c. Sim, comprou o vermelho.
AFF bought the red
'Yes, he bought the red one.'

${ }^{33}$ There might be languages that mostly rely on prosody to mark the distinction between polar confirmations and polar denials. Poletto and Zanuttini (this issue) propose that in Italian different syntactic patterns are associated with each kind of responding move; Holmberg (this issue), to the contrary, proposes a uniform syntactic pattern for English (with the consequence that his notion of 'emphatic polarity' is less restrictive than the one adopted in the current paper).

${ }^{34}$ As one of the reviewers notes such correlation between word order and unmarked vs. emphatic polarity does not arise in Brazilian Portuguese. This is because sim has practically vanished in BP both as a minimal answer to a yes/no question and as the initial element of extended affirmative answers. In colloquial BP, sim only occurs naturally in sentence-final position. This positional restriction seems to have had the effect of extending the use of the earlier emphatic sentences to pragmatically unmarked contexts. So the relevant opposition between unmarked and emphatic came to be primarily marked prosodically. I will not explore here the possibility that the prosodic distinction may have a syntactic counterpart, with no effect on surface word order. This could account for other differences between EP and BP as for the syntax of sim, but I will have to leave this topic open for future research. 
(57) [A] a. Ele não comprou o carro vermelho(.)/(, pois não?) he not bought the car red POIS NEG 'He didn't buy the red car(.)/(, did he?)'

[B] b. Comprou sim. (with overall rising intonation) bought AFF 'Yes, he DID.'

c. Comprou o vermelho sim. (with overall rising intonation) bought the red AFF 'Yes, he did buy the red one.'

An effect similar to that displayed by sim sentences can be observed in sentences with the word pois. This is a polar word with the particularity of requiring as antecedent an assertion and so being unable to constitute a grammatical answer to a yes/no question. This is illustrated by the contrast between the ungrammaticality of (58) and the availability of (59)-(60).

(58) [A] a. Ele comprou um carro? he bought a car 'Did he buy a car?'

b. *Pois.

POIS

C. Sim.

AFF

'Yes.'

(59) [A] a. Ele comprou o carro vermelho.

he bought the car red

'He bought the red car.'

[B] b. Pois comprou.

POIS bought

'In fact he did.' 
(60) [A] a. Ele não comprou o carro vermelho.

he not bought the car red

'He didn't buy the red car.'

[B] b. Pois não (comprou).

POIS not bought

'In fact he didn't.'

Just like sim, the word pois appears in initial position in confirming responding assertions (both affirmative and negative), as exemplified in (59)-(60) above, but occurs instead in final position in reversing/denying responding assertions, as shown in (61) below. The account given earlier for the word order facts observed with sim sentences naturally extends to pois sentences.

(61) $[\mathrm{A}]$ a. Ele não comprou o carro vermelho. he not bought the car red 'He didn't buy the red car?'

[B] b. Comprou pois. bought POIS

c. *Pois comprou. POIS bought 'Yes, he DID.'

A significant observation with respect to pois is the contrast between the availability of (60b) and the ungrammaticality of (62b). The fact that pois smoothly co-occurs with negation when in sentence-initial position (i.e. in confirmations) but excludes negation when in sentence-final position (i.e. in denials) shows that the latter type of structure is derived not only with IP-topicalization but also with verb movement to $\Sigma$ (just like sentence-final sim structures). So sentences like (62b) below are ungrammatical because the neg-head and the verb compete for the same position. Sentences with non-reversed word order (i.e. sim-initial and pois-initial sentences), on the other hand, do not necessarily involve verb movement to $\Sigma$ and are thus compatible with negation (see (60b) and footnote 19). 
(62) $[\mathrm{A}]$ a. Ele comprou o carro vermelho.

he bought the car red

'He bought the red car.'

[B] b. *Não comprou \{pois/sim\}.

not bought POIS/AFF

'No, he did NOT.'

5. Emphatic negation - some parallels, and avenues for further research

In European Portuguese, emphatic negative sentences display a parallel structure to emphatic affirmative sentences with sentence-final sim, except for verb movement to $\Sigma$, since the $\Sigma$-head is already filled by não 'not' (Laka 1990, Martins 1994). Example (63) shows how EP emphatic negative sentences are built with the contribution of two negative items that undergo negative concord, namely the preverbal predicative negation marker não 'not' and the sentence-final reinforcer não 'no'. The relevant structure is clarified in (63c), which is to be put in parallel with (10c) above.
(63) $[\mathrm{A}]$ a. $O$ João comprou um carro.
the João bought a car
'João bought a car.'

[B] b. O João não comprou um carro não. [rising intonation] the João not bought a car no 'João did NOT buy a car.'

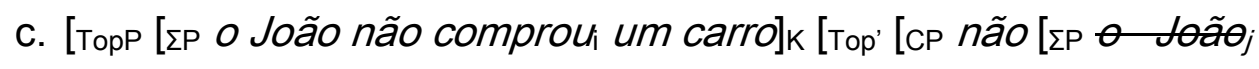
the João not bought a car no the João

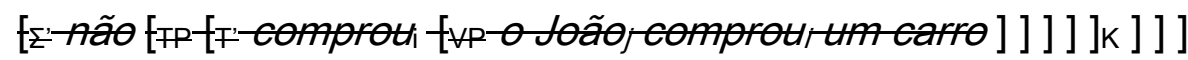
not bought the João bought a car

Because the derivation of sentences like (63) above does not involve verb movement to $\mathrm{C}$ (similarly to sentence-final sim sentences), such sentences are a grammatical option in European Portuguese and Brazilian Portuguese as well. Thus sentence (63-B) belongs to both varieties of Portuguese. This is by itself clear evidence that "double negation" emphatic sentences do not pattern with verb reduplication sentences but with sentence-final sim sentences. 
Portuguese (both EP and BP) has two homophonous words não. One of them can occur in isolation while the other is strictly preverbal, only clitics being allowed to disrupt its adjacency with the verb. This is illustrated with the European Portuguese example in (64).

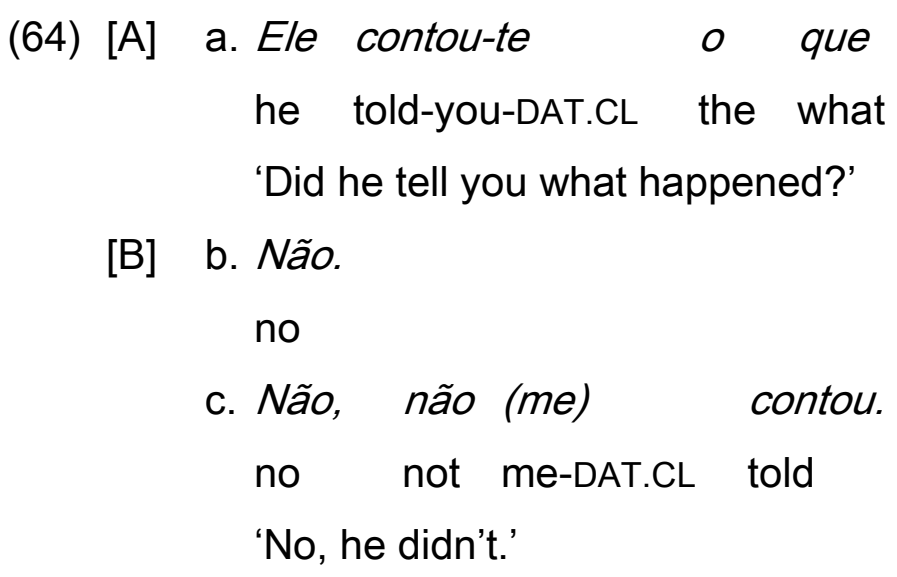

Evidence that the preverbal predicative negation marker não ('not') and the sentence-final negative word não ('no') are distinct, though homophonous, is unmistakable, as the EP data displayed in (65) and (66) demonstrate. While the former is strictly dependent on the verb form, thus requiring adjacency with it, as illustrated in (65), the latter, as exemplified in (66), can occur (a) in isolation, (b) in sentence-final position after the complementizer que 'that', (c) in sentence-final position expressing emphatic negation, (d) sandwiched between two occurrences of $q u e$ in a recomplementation structure, (e) in initial position in answers to yes/no questions.

(65) $[\mathrm{A}]$ a. $O$ João ontem cantou? the João yesterday sang

'Did João sing yesterday?'

[B] b. Não, ontem não cantou. no yesterday not sang

c. *Não, não ontem cantou. no not yesterday sang

'No, he didn't.'

d. Sim, ontem cantou. 
yes yesterday sang

'Yes, he did.'

(66) (a) Ele vem? Não.

he comes? no

'Is he coming? No.'

(b) Ele vem? Ele disse que não.

he comes? he said that no

'Is he coming? He said he isn't.'

(c) Ele vem, não vem? Não vem não.

he comes, not comes? not comes no

'He is coming, isn't he? No, he is not.'

(d) Ele vem? Ele disse que não que não vem.

he comes? he said that no that not comes

'Is he coming? He said that he is not coming.'

(e) Ele vem? Não, não vem.

he comes? no not comes

'Is he coming? No, he isn't.'

In all respects, the negative adverbial word não ('no') syntactically behaves like its responsive-partner sim 'yes', as the comparison between (66) above and (67) below makes clear. To the contrary, the predicative negation marker não ('not') has no overt positive morpho-syntactic counterpart. The data in (65) to (67) indicate that the internal predicative negation marker não ('not') is to be analyzed as a $\Sigma$-head while external/autonomous não ('no') is to be analyzed as a C-element, just like sim.

(67) (a) Ele vem? Sim.

he comes? AFF

'Is he coming? No.'

(b) Ele vem? Ele disse que sim.

he comes? he said that AFF

'Is he coming? He said he is.' 
(c) Ele não vem? Vem sim. he not comes? comes AFF 'Is he not coming? He is coming.'

(d) Ele vem? Ele disse que sim que vem. he comes? he said that AFF that comes 'Is he coming? He said that he is coming.'

(e) Ele vem? Sim, vem. he comes? AFF comes

'Is he coming? Yes, he is.'

Like the two types of emphatic affirmative sentences available in European Portuguese, emphatic negative sentences with sentence-final não ('no') are confined to root clauses in EP (cf. section 4.1.6). The EP sentence (68d) is ungrammatical, in contrast to (68c) and (68b), because it displays the C-word não ('no') in a subordinate clause. ${ }^{35}$

(68) [A] $O$ João disse que vendeu 0 carro. the João said-3SG that sold-3SG the car 'João said that he sold the car.'

[B] a. $O$ João não disse que vendeu 0 carro. the João not said-3SG that sold-3SG the car 'João didn't say that he sold the car.'

b. $O$ João não disse que vendeu $o$ carro não. the João not said-3SG that sold-3SG the car no 'João did NOT say that he sold the car.'

c. $O$ João disse que não vendeu 0 carro. the João said-3SG that not sold-3SG the car 'João said that he didn't sell the car.'

\footnotetext{
35 Differently from European Portuguese, Brazilian Portuguese allows (68d) as a grammatical option. Besides, it permits the use of the double-negation sentences under discussion in non-emphatic contexts. The observations made in footnote 34 relative to sentence-final sim sentences extend to the present case.
} 


\section{d. *O João disse que não vendeu o carro não. the João said-3SG that not sold-3SG the car no 'João said that he did NOT sell the car.'}

The analysis presented in this section for sentence-final não ('no') emphatic sentences in European Portuguese makes the right predictions with respect to their availability in Brazilian Portuguese because such sentences are derived without verb movement to $\mathrm{C}$. Since their derivation does not involve verb movement to $\Sigma$ either, we should expect that this same strategy would be more generally available in the Romance languages. This is in fact the case for Catalan, Spanish and Italian. See Batllori and Hernanz (this issue), from whom the sentences in (69) are taken. ${ }^{36}$ The Italian example in (70) was kindly provided by one of the reviewers.
a. No ha cantado la soprano, no. Spanish not has sung the soprano no
b. No ha cantat la soprano, no.
Catalan
not has sung the soprano no
'The soprano didn't sing.'

(70) A: Gianni ha comprato un'auto.

Gianni has bought a car

'Gianni bought a car.'
B: Non I' ha comprata no. Italian
not it has bought no
'No, he did not (buy a car).'

On the other hand, the negative counterpart of the si que strategy is found in Catalan and in Italian but not in Spanish, although sixteenth century Spanish allowed it (see (71a-d)). The variation displayed by the Romance languages with respect to the expression of emphatic negation is an issue that needs to be further scrutinized

\footnotetext{
${ }^{36}$ Parallel affirmative sentences with two síwords, one of them presumably a $\Sigma$-word merged in $\Sigma \mathrm{P}$, the other a C-word merged in CP, are attested in Spanish and Catalan, which indicates that these languages have two homophonous síin tandem with two homophonous no. See section 4.2 above.
} 
and understood (see Poletto and Zanuttini, this issue). In spite of the present shortcomings, it is clear enough that we are dealing with syntactic variation, which confirms that emphatic polarity in Romance is a matter of syntax.

'NEG-COMP-NEG' emphatic negative sentences: ${ }^{37}$

(71) a. No que no la sé, la notícia.

no that not it know-1SG, the news

'I do not know about the news.'

(Catalan. From Badia Margarit (1995:723))

b. No che non voglio ballare.

no that not want-1SG dance-INFIN

'I do not want to dance.'

(Italian. From Bernini (1995:176))

c. *No que no vendré.

no that not will-sell-1SG

'I will not sell.'

${ }^{37}$ European Portuguese allows 'NEG-COMP-NEG' sentences only as a means to express disagreement with respect to a preceding negative assertion, as exemplified below. This type of structure is not found in Brazilian Portuguese. It might be the case that such sentences as illustrated in (i-B), to be contrasted with (ii-B-a), express metalinguistic negation (cf. Horn 1989, Martins 2010, forthcoming), not standard negation.

European Portuguese

(i) $[\mathrm{A}] \mathrm{Não}$ vou comer a sopa.

not go-1SG eat-INFIN the soup

'I will not eat the soup.'

[B] Não que não comes.

no that not eat-2SG

'Yes you will!'

(ii) [A] Come a sopa. eat-IMP the soup

'Eat your soup.'

[B] a. *Não que não como. no that not eat-2SG

b. Não como não.

not eat-1SG no

'I will NOT!' 
(Spanish. From Brucart (1999:2836))
d. No que no lo mandó.
no that not it ordered-3SG
'He did not order it.'

(16th c. Spanish. From Keniston (1937: 679))

\section{Conclusion}

This paper discusses emphatic polarity in European Portuguese with the aim to account not only for what exists in the language but also for the limited crosslinguistic availability of some EP structures and the fact that EP bars alternative structures that are shared by most Romance languages.

Three types of syntactic strategies to express emphatic affirmation are dealt with in the paper: (i) the verb reduplication pattern, which is restricted to European Portuguese and Galician; (ii) the si que pattern, which is found in most Romance languages but excluded in European and Brazilian Portuguese; (iii) the sentencefinal sim/sípattern, which is available in all the Romance languages considered in the paper (namely, European and Brazilian Portuguese, Galician, Spanish, Catalan and Italian). The emphatic verb reduplication structures are incompatible with negation. The other two patterns have correlates on the negation side: the no que no structures replicate de sí que ones; the sentence-final não/no structures replicate the sentence-final sim/síones (with some qualification).

The paper elaborates on the basic idea that the functional heads $\Sigma$ and $C$ require phonological realization in emphatic polarity structures and independent grammatical/lexical differences between languages determine the different ways such requirement is satisfied. ${ }^{38}$ By developing this line of reasoning, it was possible to account for all the EP structures, while concomitantly deriving the cross-linguistic variation relative to the emphatic affirmation structures and partially the emphatic

\footnotetext{
38 For example, the hypothesis that the verb can satisfy the strong/PF requirement of $\Sigma$ in European Portuguese but not in Spanish, Catalan or Italian derives not only the contrast between the two sets of languages relative to the availability of the emphatic verb reduplication structure but also other nontrivially related differences, namely: only EP has bare verb answers to yes/no questions, allows VP Ellipsis and displays enclisis in finite clauses (see Martins 1994; Costa et al. 2012).
} 
negation ones. Several issues brought up throughout the paper were signaled for future research.

Besides the way $\mathrm{C}$ and $\Sigma$ interact to convey emphatic polarity, one additional trait could be identified that links together the data examined in the paper. In all types of structure expressing emphatic polarity (in the restrictive sense adopted in the paper), a bare polar word gets focus stress and agrees in polarity value with the clausal constituent it is paired with. But either the focus configuration is established through an 'extract-out-of-focus-strategy' that leaves in the sentence-final position the polarity expressing word to which unmarked focus stress is assigned, or the focus configuration obtains through Focus-movement into the left periphery.

The facts discussed in this work offer clear evidence that syntax deals with the distinction between confirming responding assertions and denying responding assertions. That is to say, by observing the European Portuguese and other Romance language data we know that the relevant distinction is syntactically expressed in natural language although there may be room to admit that not all languages resort to syntax to convey it. The facts considered in the paper also suggest that that the opposition same/reverse is not as central to the syntax of emphatic polarity as the opposition confirmation/denial (see Farkas and Bruce 2010).

\section{ACKNOWLEGEMENTS}

I am most grateful to the organizers of the GIST workshop on emphatic polarity (Gent, 29-30 September 2011) for making this paper possible and to organizers and participants together for very illuminating discussion. Anders Holmberg, Montse Batllori and Cecilia Poletto, in particular, have been a continuing source of new data and inspiration. Many thanks are also due to the three anonymous reviewers for Lingua.

The author's research is funded by FCT - Fundação para a Ciência e a Tecnologia.

\section{REFERENCES}

Álvarez, R., Xove, X., 2002. Gramática da Lingua Galega. Galaxia, Vigo.

Ambar, M., 1992. Para uma Sintaxe da Inversão Sujeito-Verbo em Português. Colibri, Lisboa.

Badia Margarit, A. M., 1995. Gramàtica de la Llengua Catalana. Proa, Barcelona. 
Bernini, G., 1995. Le profrasi. In: Renzi, L., Salvi, G., Cardinaletti, A. (Eds.), Grande

Grammatica Italiana de Consultazione, vol. 3. II Mulino, Roma, pp. 175-222.

Bošković, Ž., Nunes, J., 2007. The Copy Theory of Movement: A view from PF. In:

Corver, N., Nunes, J. (Eds.), The Copy Theory of Movement. John Benjamins, Amsterdam/Philadelphia, pp. 13-74.

Britto, H., 1998. Deslocamento à Esquerda, Resumptivo-Sujeito, Ordem SV e a Codificação Sintática de Juízos Categórico e Tético no Português do Brasil. Ph.D. dissertation. Universidade Estadual de Campinas (UNICAMP).

Brucart, J. M., 1999. La Elipsis. In: Bosque, I., Demonte, V. (Eds.), Gramática

Descriptiva de la Lengua Española. Espasa, Madrid, pp. 2787-2863.

Chomsky, N., 1995. The Minimalist Program. MIT Press, Cambridge/ London.

Chomsky, N., 2000. Minimalist Inquiries: The Framework. In: Martin, R., Michaels, D., Uriagereka, J. (Eds.), Step by Step: Essays on Minimalist Syntax in Honor of Howard Lasnik. MIT Press, Cambridge/London, pp.89-155.

Chomsky, N., 2001. Derivation by Phase. In: Kenstowicz, M. (Ed.), Ken Hale: A Life in Language. MIT Press, Cambridge/London, pp. 1-52.

Costa, J., 1998. Word Order Variation: A constraint-based approach. Holland Academic Graphics, The Hague.

Costa, J., 2004. Subject Positions and the Interfaces: The Case of European Portuguese. Mouton de Gruyter, Berlin/New York.

Costa, J. et al., 2012. VP Ellipsis: New Evidence from Capeverdean Creole. In: Franco, I., Lusini, S., Saab, A. (Eds.), Romance Languages and Linguistic Theory 4. John Benjamins, Amsterdam/Philadelphia, pp. 155-175.

Duarte, I., Matos, g., 2000. Romance Clitics and the Minimalist Program. In: Costa, J. (Ed.), Portuguese Syntax: New Comparative Studies. Oxford University Press, Oxford/New York, pp. 116-142.

Farkas, D. F., Bruce, K. B., 2010. On Reacting to Assertions and Polar Questions. Journal of Semantics 27, 81-118.

Halle, M., Marantz, A. 1993. Distributed Morphology and the Pieces of Inflection. In: Hale, K., Keyser, S. J. (Eds.); The View from Building 20: Essays in Linguistics in Honor of Sylvain Bromberger. MIT Press, Cambridge/London,.pp. 111-176.

Holmberg, A., 2001. The syntax of Yes and No in Finnish. Studia Linguistica 55, 141 175. 
Holmberg, A., 2003. Questions, answers, polarity and head movement in Germanic and Finnish. In: Dahl, A., Bentzen, K., Svenonius, P. (Eds.), Proceedings of the 19th Scandinavian Conference of Linguistics (= Nordlyd, University of Toms $\varnothing$ Working Papers on Language and Linguistics 31, 88-115).

Holmberg, A., 2005. Null Subjects and Polarity Focus. In: Bateman, L., Ussery, Ch. (Eds.), Proceedings of the thirty-fifth annual meeting of the North East Linguistic Society, University of Connecticut, Storrs, October 22-24, 2004. GLSA (Graduate Linguistics Student Association), Dpt. of Linguistics, South College, University of Massachusetts, Amherst, MA, pp. 21-42.

Holmberg, A., 2007. Null subjects and polarity focus. Studia Linguistica 61, 212-236. Horn, L. R., 1989. A Natural History of Negation. CSLI Publications. 2001.

Kandybowicz, J., 2007. On fusion and multiple copy spell-out: The case of verbal repetition. In: Corver, N., Nunes, J. (Eds.), The Copy Theory of Movement. John Benjamins, Amsterdam/Philadelphia, pp. 119-150.

Kato, M., Roberts, I. (Eds.). 1996. Português Brasileiro: Uma Viagem Diacrônica. Campinas. Editora da UNICAMP, São Paulo.

Kayne, R., 1994. The Antisymmetry of Syntax. MIT Press, Cambridge/London. Keniston, H., 1937. The Syntax of Castillian Prose: The Sixteenth Century. The University of Chicago Press, Chicago/Illinois.

Laka, I., 1990. Negation in Syntax: On the Nature of Functional Categories and Projections. Ph. D. dissertation. MIT.

Lobo, M., 2003. Aspectos da Sintaxe das Orações Subordinadas Adverbiais do Português. Ph.D. dissertation. Universidade Nova de Lisboa.

Martins, A. M., 1994. Clíticos na História do Português. Ph.D. dissertation. Universidade de Lisboa.

Martins, A. M., 1994. Enclisis, VP-deletion and the nature of Sigma. Probus 6, 173205.

Martins, A. M., 2007. Double realization of verbal copies in European Portuguese emphatic affirmation. In: Corver, N., Nunes, J. (Eds.), The Copy Theory of Movement. John Benjamins, Amsterdam/Philadelphia, pp. 77-118.

Martins, A. M., forthcoming. How much syntax is there in metalinguistic negation? Natural Language and Linguistic Theory. 
Mateus, M. H., d'Andrade, E., 2000. The Phonology of Portuguese. Oxford University Press, Oxford/New York.

Nunes, J., 2001 Sideward Movement. Linguistic Inquiry 32, 303-344.

Nunes, J., 2004 Linearization of Chains and Sideward Movement. MIT Press, Cambridge/London.

Oltra-Massuet, I., Arregi, K., 2005. Stress-by-Structure in Spanish. Linguistic Inquiry $36,43-84$.

Pope, E. N., 1976. Questions and Answers in English. Mouton, The Hague.

Roberts, I., 1992. A formal account of grammaticalization in the history of Romance futures. Folia Linguistica Historica 13, 219-258.

Roberts, I., 1997. Restructuring, Head Movement, and Locality. Linguistic Inquiry 28, 423-460.

Roberts, I., 2001. Language Change and Learnability. In: Bertolo, S. (Ed.), Language Acquisition and Learnability. Cambridge University Press, Cambridge, pp. 81-125. Roberts, I., 2004. The C-system in Brythonic Celtic Languages, V2, and the EPP. In: Rizzi, L. (Ed.), The Structure of CP and IP: The Cartography of Syntactic Structures, vol. 2. Oxford University Press, Oxford/new York, pp. 297-296. Roberts, I., Roussou, A. 2002. The History of the Future. In: Lightffot, D. (Ed.), Syntactic Effects of Morphological Change. Oxford University Press, Oxford/New York, pp. 23-56.

Roberts, I., Roussou, A., 2003. Syntactic Change: A Minimalist Approach to Grammaticlization. Cambridge University Press, Cambridge.

Wurmbrand, S., 2001. Infinitives: Restructuring and Clause Structure. Mouton de Gruyter, Berlin/New York.

Zanuttini, R., 1994. Re-examining Negative Clauses. In: Cinque, G., Koster, J., Pollock, J.-Y., Rizzi, L., Zanuttini, R. (Eds), Paths Towards Universal Grammar: Studies in Honor of Richard Kayne. Georgetown University Press, Washington, D.C., pp. 427-451.

Zanuttini, R., 1997. Negation and Clausal Structure: A Comparative Study of Romance Languages. Oxford University Press, Oxford/New York. 